\title{
ॠUSGS
}

science for a changing world

Hurricane Sandy Washover Deposits on Fire Island, New York

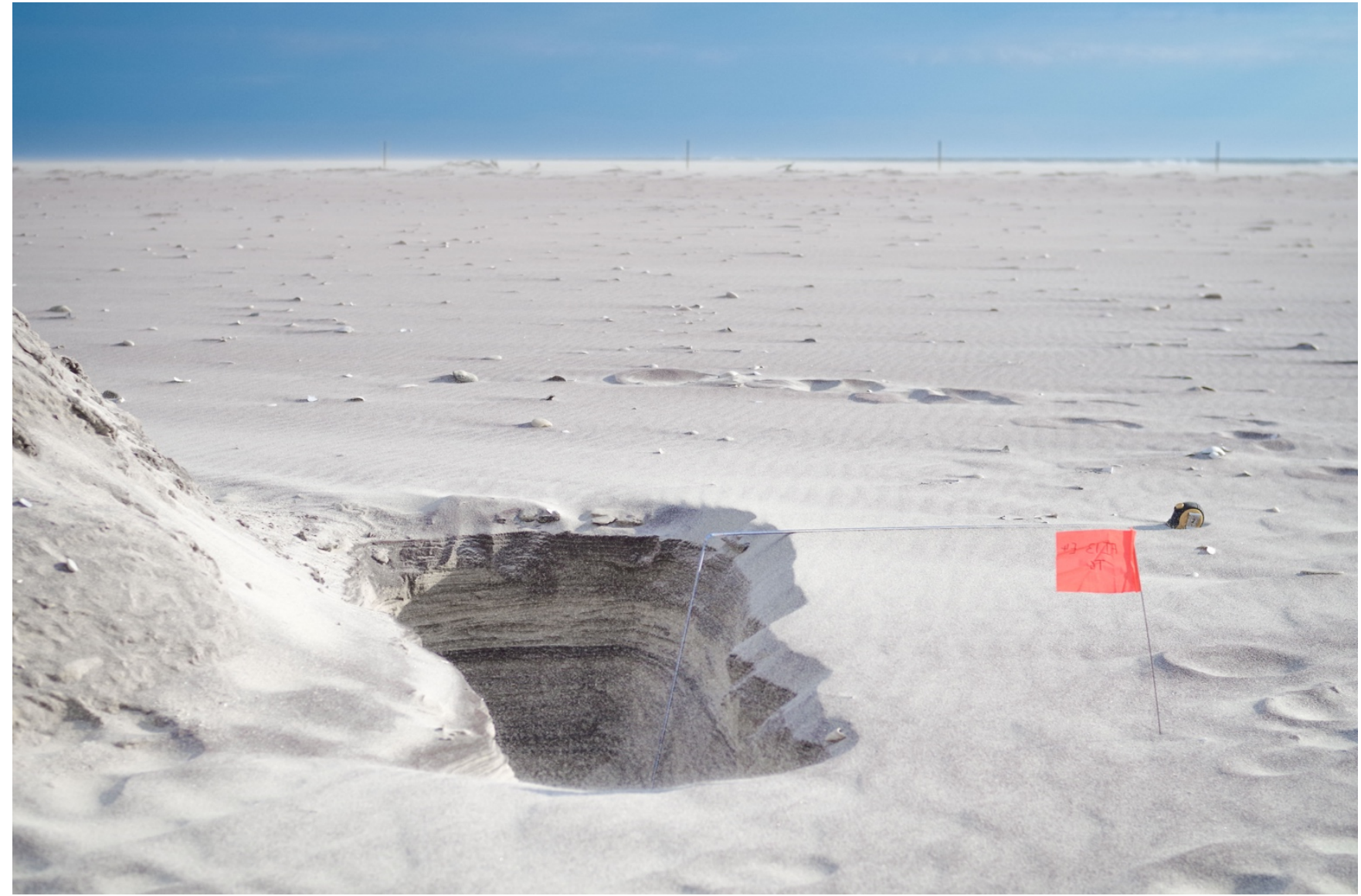

Open-File Report 2017-1014

U.S. Department of the Interior

U.S. Geological Survey 
Cover. Photograph of a trench in eastern Fire Island, New York, showing heavy mineral laminations from washover processes. Shoreline is in the background toward the upper right. (U.S. Geological Survey photograph by SeanPaul La Selle.) 


\section{Hurricane Sandy Washover Deposits on Fire Island, New York}

By SeanPaul M. La Selle, Brent D. Lunghino, Bruce E. Jaffe, Guy Gelfenbaum, and Pedro J.M. Costa

Open-File Report 2017-1014

U.S. Department of the Interior

U.S. Geological Survey 


\section{U.S. Geological Survey William H. Werkheiser, Acting Director}

U.S. Geological Survey, Reston, Virginia: 2017

For more information on the USGS—-the Federal source for science about the Earth, its natural and living resources, natural hazards, and the environment-visit https://www.usgs.gov/ or call 1-888-ASK-USGS (1-888-275-8747).

For an overview of USGS information products, including maps, imagery, and publications, visit https://store.usgs.gov.

Any use of trade, firm, or product names is for descriptive purposes only and does not imply endorsement by the U.S. Government.

Although this information product, for the most part, is in the public domain, it also may contain copyrighted materials as noted in the text. Permission to reproduce copyrighted items must be secured from the copyright owner.

Suggested citation:

La Selle, S.M., Lunghino, B.D., Jaffe, B.E., Gelfenbaum, G., and Costa, P.J.M., 2017,

Hurricane Sandy washover deposits on Fire Island, New York: U.S. Geological Survey OpenFile Report 2017-1014, 30 p., https://doi.org/10.3133/ofr20171014. 


\section{Acknowledgments}

The U.S. Geological Survey (USGS) Coastal and Marine Geology Program funded this research. We thank Katelyn Kerr, Jordan Raphael, Michael Bilecki, and Chris Soller at the National Park Service, Fire Island National Seashore, who were invaluable in providing access to the field sites. Cheryl Hapke (USGS St. Petersburg Coastal and Marine Science Center) provided background and logistical support, and we thank her for sharing her wealth of experience on Fire Island. Angela Lam (USGS) performed the grain-size analysis of the bulk sediment samples. Piero Bellanova (RWTH Aachen University) processed CT scan images and performed the grain size-analysis on the core from trench T3. F.C. Lira (University of Lisbon) performed the microtextural analysis. We would also like to thank Owen Brenner and James Bishop for their insightful reviews. 


\section{Contents}

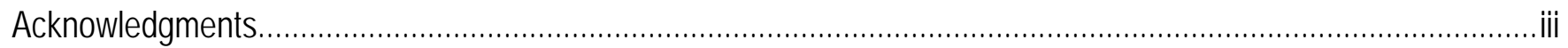

Abstract ……

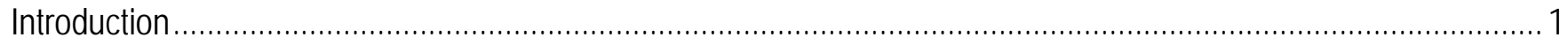

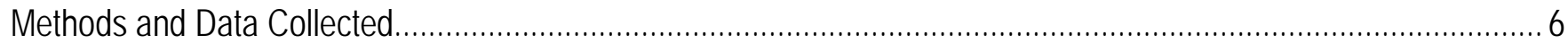

Deposit Characterization …………………………

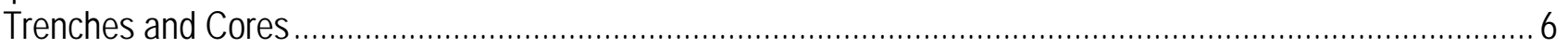

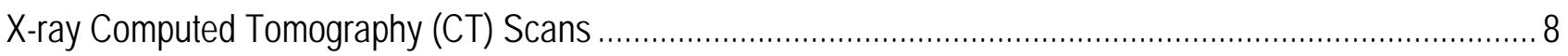

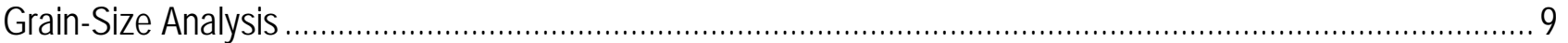

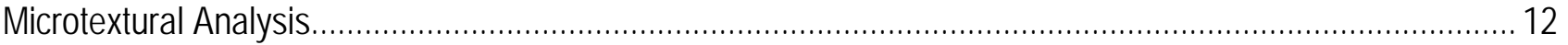

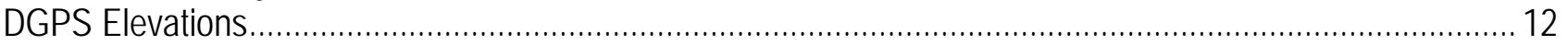

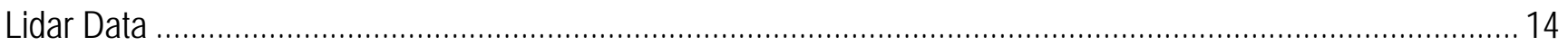

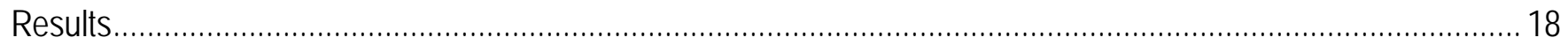

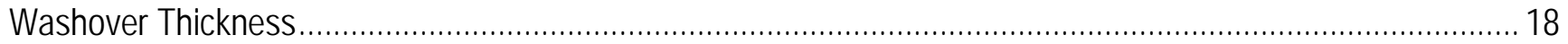

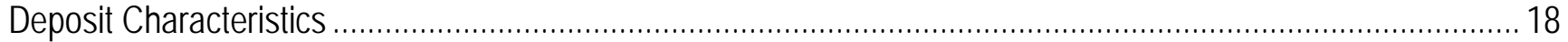

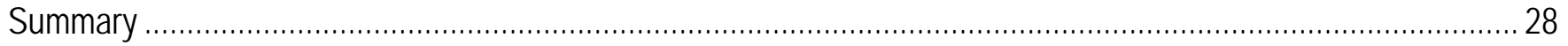

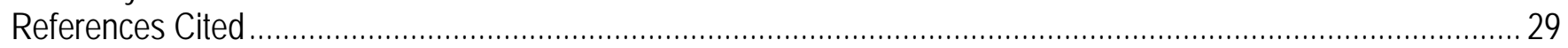

\section{Figures}

1. Location map of Fire Island, New York, along the southern shore of Long Island, New York. Field localities are represented by boxes labeled "West" and "East."

2. Map/satellite image of the east field site on Fire Island, New York, showing the Global Positioning System (GPS) topography transects and trenches

3. Map/satellite image of the west field site on Fire Island, New York, showing Global Positioning (GPS) topography transects

4. Map/satellite image of the east field site on Fire Island, New York, with sampling locations and Global Positioning System (GPS) transects shown on June 21, 2013, imagery collected almost 7 months after Hurricane Sandy

5. Photographs of push core and U-channel sampling at trench T3 (fig. 4) on Fire Island, New York .............. 8

6. Photographs of collecting bulk sediment samples out of a trench wall and collecting sand samples (right for grain size and microtextural analyses on Fire Island, New York

7. Scanning electron microscope photographs showing microtextural features of quartz grains from Fire Island, New York

8. Histograms of the 95th percentile vertical and horizontal precision for the Differential Global Positioning System surveys done on Fire Island, New York.

9. Map showing deposition and erosion inferred from differencing pre- and post-Hurricane Sandy lidar data from Fire Island, New York

10. Graph showing measured versus inferred (from Differential Global Positioning System, pre-Hurricane Sandy lidar elevations) sediment-deposit thicknesses from Fire Island, New York.

11. Graphs showing median grain size (D50), deposit thickness, and surface elevation as a function of distance from shore along the east field site transect (fig. 2) on Fire Island, New York

12. Diagram showing trench photograph, grain-size distributions for bulk sediment samples, graph comparing grain-size distributions, and table with stratigraphic description for trench T5 on Fire Island, New York. 
13. Diagram showing core photograph, x-ray computed tomography (CT) scan, trench photograph, grain-size distributions for bulk sediment samples, graph comparing grain-size distributions, and table with stratigraphic description for trench T4 on Fire Island, New York.

14. Diagram showing core photograph, x-ray computed tomography (CT) scan, trench photograph, grain-size distributions for bulk sediment samples, graph comparing grain-size distributions, and table with stratigraphic description for trench T3 on Fire Island, New York....

15. Diagram showing trench photograph, grain-size distributions for bulk sediment samples, graph comparing grain-size distributions, and table with stratigraphic description for trench T2 on Fire Island, New York.

16. Diagram showing core photograph, $x$-ray computed tomography (CT) scan, trench photograph, grain-size distributions for bulk sediment samples, graph comparing grain-size distributions, and table with stratigraphic description for trench T1 on Fire Island, New York.

17. Diagram showing core photograph, x-ray computed tomography (CT) scan, trench photograph, grain-size distributions for bulk sediment samples, graph comparing grain-size distributions, and table with stratigraphic description for trench 77 on Fire Island, New York.....

18. Diagram showing trench photograph, grain-size distributions for bulk sediment samples, graph comparing grain-size distributions, and table with stratigraphic description for trench T8 on Fire Island, New York.....

19. Diagram showing trench photograph, grain-size distributions for bulk sediment samples, graph comparing grain-size distributions, and table with stratigraphic description for trench T9 on Fire Island, New York.

20. Diagram showing core photograph, $\mathrm{x}$-ray computed tomography (CT) scan, and detailed, stacked grain-size distributions for core FI13-E4-T3-PC2

21. Graphs showing principal component analysis of microtextural features in sediment samples from Fire Island, New York.

\section{Tables}

1. Push-core sample inventory from Fire Island, New York 10

2. U-channel sample inventory from Fire Island, New York

3. Bulk-sediment sample inventory from Fire Island, New York

4. Surveyed minimum flow depth indicators at the west field site on Fire Island, New York 14

5. Microtextural analysis from scanning electron microscope (SEM) data from sediment samples collected

on Fire Island, New York.

\section{Datum}

Vertical coordinate information is referenced to the North American Vertical Datum of 1988 (NAVD 88). Horizontal coordinate information is referenced to the North American Datum of 1983 (NAD 83). 


\title{
Hurricane Sandy Washover Deposits on Fire Island, New York
}

\author{
By SeanPaul M. La Selle, ${ }^{1}$ Brent D. Lunghino, ${ }^{1}$ Bruce E. Jaffe, ${ }^{1}$ Guy Gelfenbaum, ${ }^{1}$ and Pedro J.M. Costa ${ }^{2}$
}

\begin{abstract}
Washover deposits on Fire Island, New York, from Hurricane Sandy in 2012 were investigated a year after the storm to document the sedimentary characteristics of hurricane washover features. Sediment data collected in the field includes stratigraphic descriptions and photos from trenches, bulk sediment samples, U-channels, and gouge and push cores. Samples and push cores were further analyzed in the laboratory for grain size, density variations using x-ray computed tomography (CT), and surface microtexture using a scanning electron microscope (SEM). Elevation profiles of washover features were measured using Differential Global Positioning System (DGPS) with Real Time Kinematic processing. The DGPS elevations were compared to lidar (light detection and ranging) data from pre- and post-Sandy surveys to assess the degree to which washover deposit thicknesses changed within the year following deposition. Hurricane Sandy washover deposits as much as 1 meter thick were observed in trenches. Initial results show that the upper parts of the deposits have been reworked significantly in some places by wind, but there are still areas where the deposits are almost entirely intact. Where mostly intact, the washover deposits consist of massive or weakly laminated sand near the base, overlain by more strongly laminated sands.
\end{abstract}

\section{Introduction}

Hurricane Sandy made landfall as a post-tropical cyclone along the New York and New Jersey coasts on the evening of October 29, 2012. Hurricane Sandy was not only the largest storm in the Atlantic basin on historical record, but also the deadliest hurricane to strike the U.S. mainland since Hurricane Katrina in 2005. Storm surge and wave energy from Hurricane Sandy resulted in severe erosion of dunes and beaches along the length of Fire Island (fig. 1), a 50 kilometer (km)-long barrier island along the south coast of Long Island, New York. Although much of the sand eroded from the island was transported offshore, Hapke and others (2013) estimated that approximately 14 percent of the eroded material was deposited on the island as washover deposits.

Understanding the characteristics of modern hurricane deposits and the processes that created them improves the ability to use deposits in the geologic record to extract information about prehistoric events. A more complete understanding of the dynamics of hurricane overwash deposition is valuable for evaluating potential hazards along vulnerable coastlines. The internal stratigraphy of deposits left by extreme coastal flooding events can be used to reconstruct flow conditions (Jaffe and Gelfenbaum, 2007; Woodruff and others, 2008; Shaw and others, 2015) and can sometimes help differentiate between different types of flooding events such as hurricanes and tsunamis (Morton and others, 2007; Tuttle and

\footnotetext{
${ }^{1}$ U.S. Geological Survey.

${ }^{2}$ Universidade de Lisboa, Lisboa, Portugal.
} 


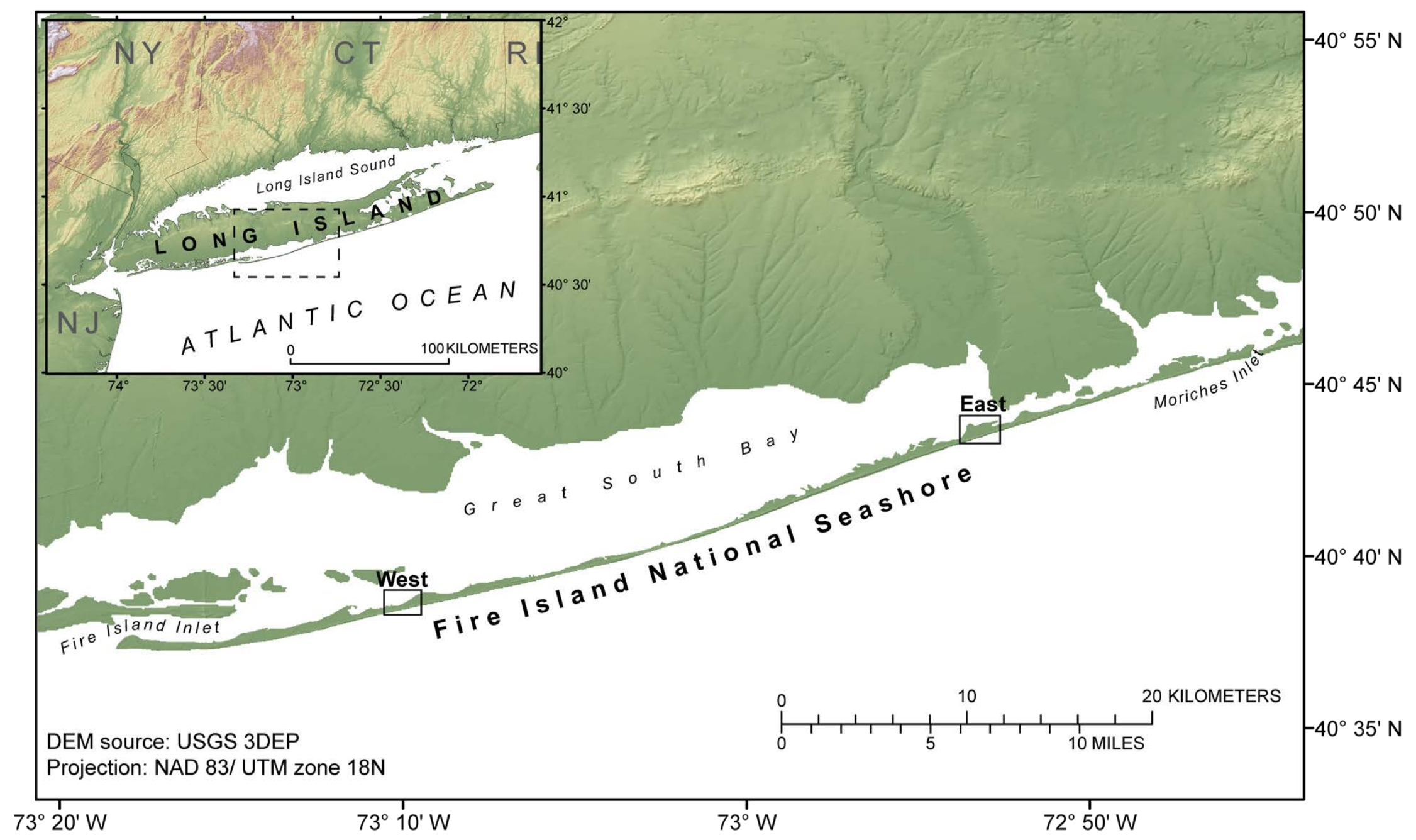

Figure 1. Location map of Fire Island, New York, along the southern shore of Long Island, New York. Field localities are represented by boxes labeled "West" and "East." 
others, 2004; Switzer and Jones, 2008; Goff and others, 2004). In their review of the current state of knowledge on coastal overwash measurements and modeling, Donnelly and others (2006) identified a lack of data with which to validate models of overwash, especially for larger storm and hurricane events where inundation overwash has occurred, such as in eastern Fire Island during Hurricane Sandy in 2012. The purpose of this report is to describe in detail the morphology and sedimentology of Hurricane Sandy overwash deposits on Fire Island, and to provide a dataset for future sedimentological and modeling studies.

Since the late 1990s, the U.S. Geological Survey (USGS) has been researching long- and shortterm behavior of the Fire Island barrier island system (Hapke and others, 2010, Lentz and Hapke, 2011). As a result of these studies, a large variety of datasets had been collected before Hurricane Sandy, making Fire Island an ideal location to perform post-storm surveys. Pre-storm (Department of Commerce and others, 2016) and post-storm lidar (light detection and ranging) (Stockdon and others, 2013) and aerial photo datasets in addition to numerous ground-based surveys of beach and dune morphology (Hapke and others, 2013) provide a large-scale picture of storm-driven coastal changes to Fire Island.

Fieldwork for this study was conducted within the Fire Island National Seashore during November 8-12, 2013, about a year after Hurricane Sandy made landfall. After a day of field reconnaissance with National Park Service (NPS) personnel, two field sites were selected to study Hurricane Sandy overwash deposits (fig. 1). A site in eastern Fire Island National Seashore was selected because it contained a prominent washover terrace, an elongate deposit oriented parallel to shore (Morton and Sallenger, 2003), with several "fingers" of washover fans extending at least 400 meters (m) from the shoreline to the back-barrier marsh (fig. 2). Just to the southwest of this site, Hurricane Sandy eroded a 6-m high dune and opened up the Wilderness breach (fig. 2). 


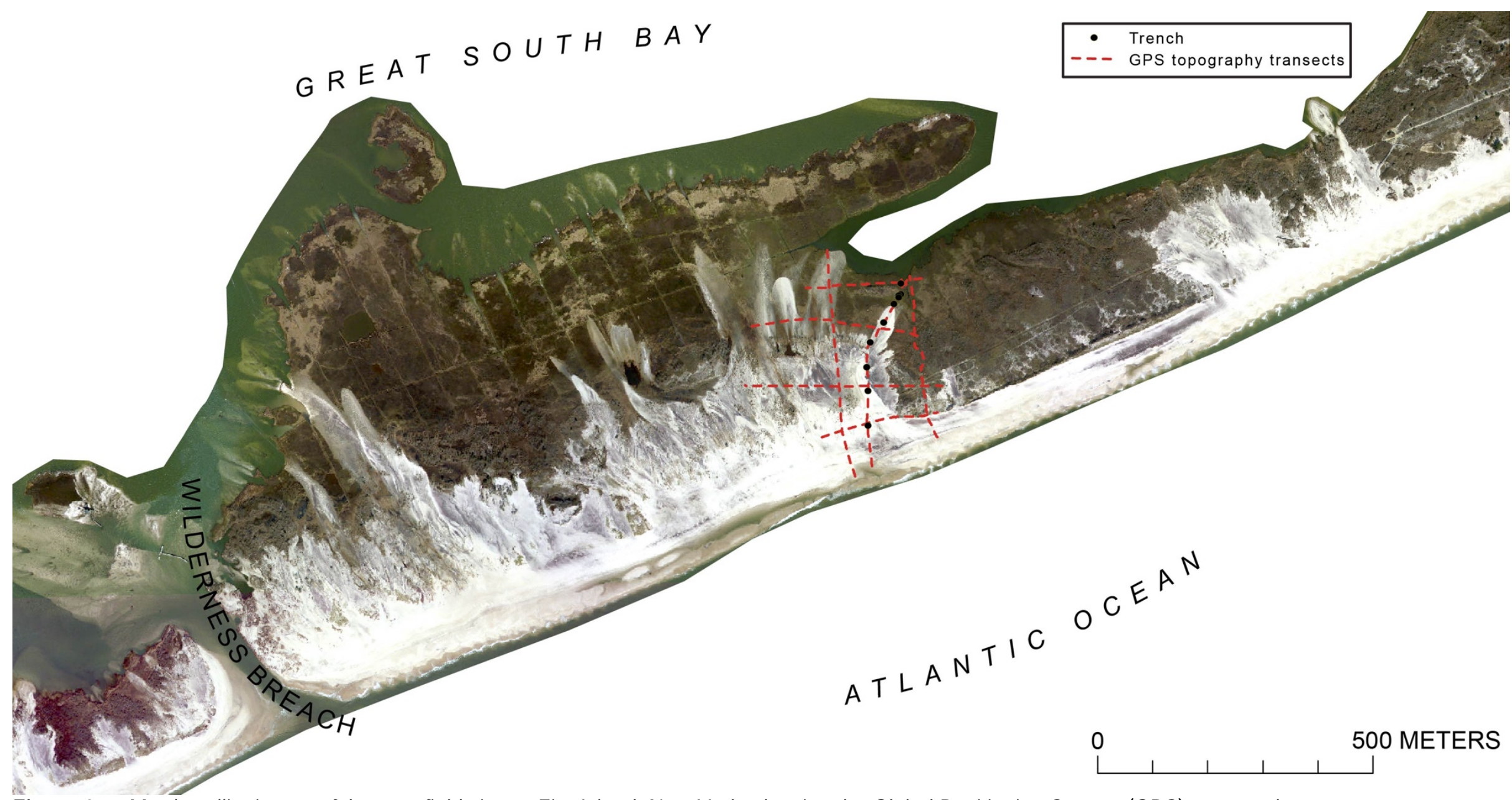

Figure 2. Map/satellite image of the east field site on Fire Island, New York, showing the Global Positioning System (GPS) topography transects (dashed red lines) and trenches (black dots). Imagery is from National Oceanic and Atmospheric Administration, National Ocean Service, National Geodetic Survey (2013) Hurricane Sandy response imagery, taken November 4, 2012. 
The west field site is located between the communities of Atlantique and Robbins Rest on a small parcel of National Seashore land (fig. 3). This site was selected because of its proximity to a water level sensor deployed just before the storm (McCallum and others, 2013; also see https:/ga.water.usgs.gov/flood/hurricane/sandy/sites/SSS-NY-SUF-017WL.html). The width of Fire Island is relatively narrow at this site (about $250 \mathrm{~m}$ across), and the lagoon side of the dune is forested. Indicators of minimum water depth, such as leaves and twigs wrapped around trees, were surveyed to complement the water-level data recorded at the shoreline.

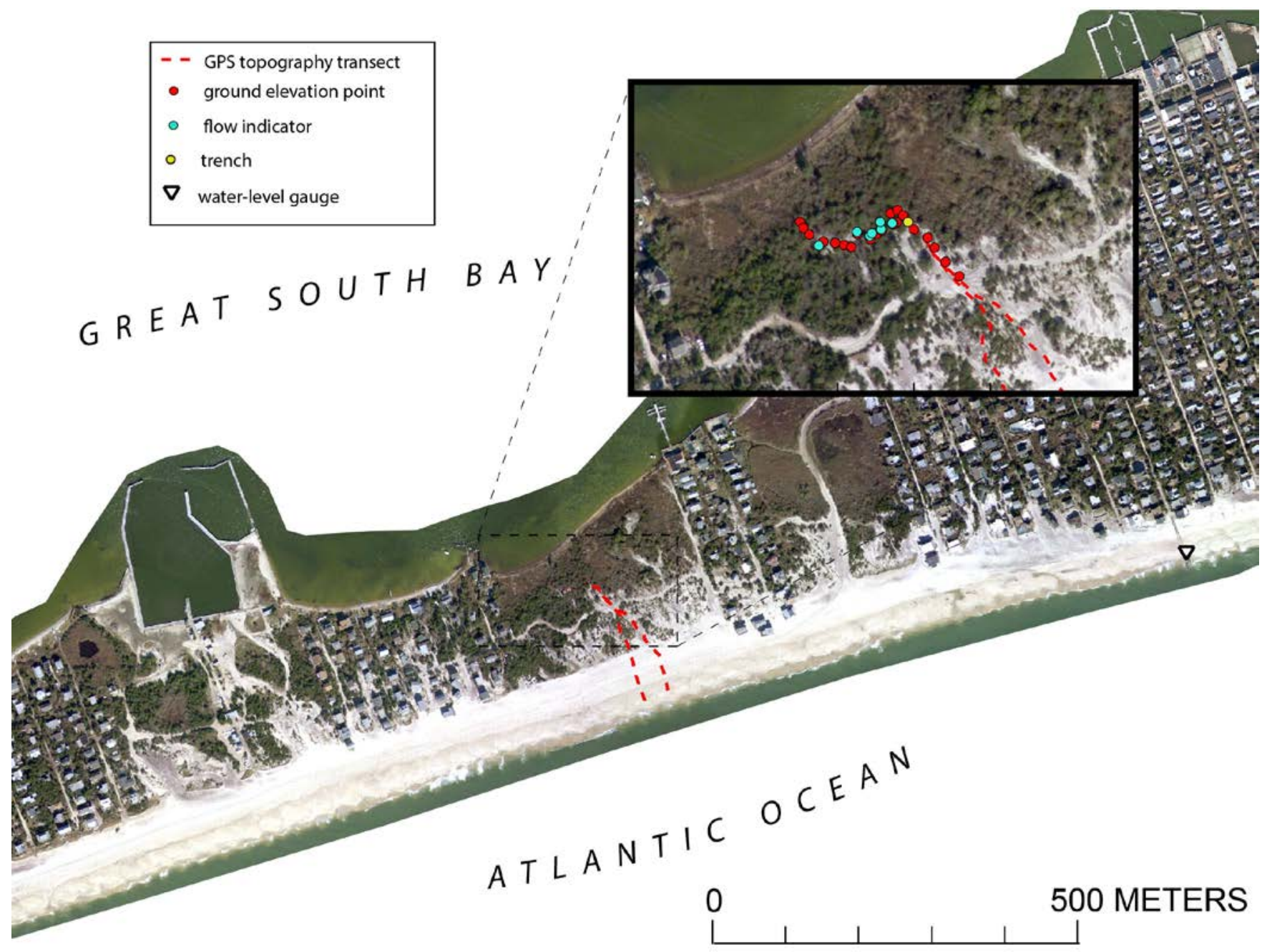

Figure 3. Map/satellite image of the west field site on Fire Island, New York, showing Global Positioning System (GPS) topography transects (dashed red lines). The west field site lies between the communities of Atlantique (left) and Robbins Rest (right). The inset shows points where flow-depth indicators (light blue dots), surface elevations (red dots), and a trench (yellow dot) were surveyed. Imagery is from National Oceanic and Atmospheric Administration, National Ocean Service, National Geodetic Survey (2013) Hurricane Sandy response imagery, taken November 4, 2012. 


\section{Methods and Data Collected}

\section{Deposit Characterization}

Trenches and cores were collected on a shore-perpendicular transect along a washover fan in the east field site in order to describe the sedimentology and record the thickness of the Hurricane Sandy deposit. Samples were taken from trench walls for grain-size analysis and for a microtextural analysis. Plastic push cores were collected to take computed tomography (CT) scans and for detailed grain-size analysis.

\section{Trenches and Cores}

Ten small trenches $(\sim 1 \times 1 \mathrm{~m})$ were excavated along part of a washover terrace and a prominent washover fan that extended into the back-barrier marsh in the east field site (fig. 4). Trench walls were oriented parallel to the interpreted flow direction and were excavated down to the pre-Hurricane Sandy surface, which was identified in the field as a brown, rooted peat or soil. Total deposit thicknesses were measured from the washover surface down to the pre-Hurricane Sandy surface.

To assess the local variability in deposit thickness, the deposit was also cored with a 30 millimeter (mm)-gouge core across the short axis of the washover fan at trenches T3, T2, and T1 (fig. 4). On average, the gouge-core deposit thicknesses were within 15 percent of the thicknesses observed in corresponding trenches, indicating minimal alongshore variability in the deposit within $10 \mathrm{~m}$ of the trenches. Two trenches, T6 and T10, did not contain Sandy overwash deposits. T6 was in line with the primary dune and was within the zone of erosion during Hurricane Sandy. T10 was located landward of the original Hurricane Sandy washover fan that is visible in post-storm aerial photos and was easily distinguished because of the presence of mud at the surface.

The stratigraphy of the washover deposit was described and photographed at each trench before being sampled. Two 5-inch-wide slab cores, nine 3-inch-diameter push cores, and ten U-channel cores (fig. 5) were collected at eight of the trenches (tables 1 and 2).

In total, 38 bulk sediment samples (fig. 6), were collected from trench walls and sites of several potential sediment sources (table 3) for grain-size analysis. Sample weights varied from 0.3 to 25 grams. The "accreted" and "old" dune surface samples were taken from the seaward face of the main dune near the edge of the washover terrace (S2 and S3 in fig. 4). The accreted dune sample was taken about 25 centimeters $(\mathrm{cm})$ below the surface where active wind ripples were observed. The old dune sample was collected from the erosional scarp, approximately $0.5 \mathrm{~m}$ below the dune crest. 


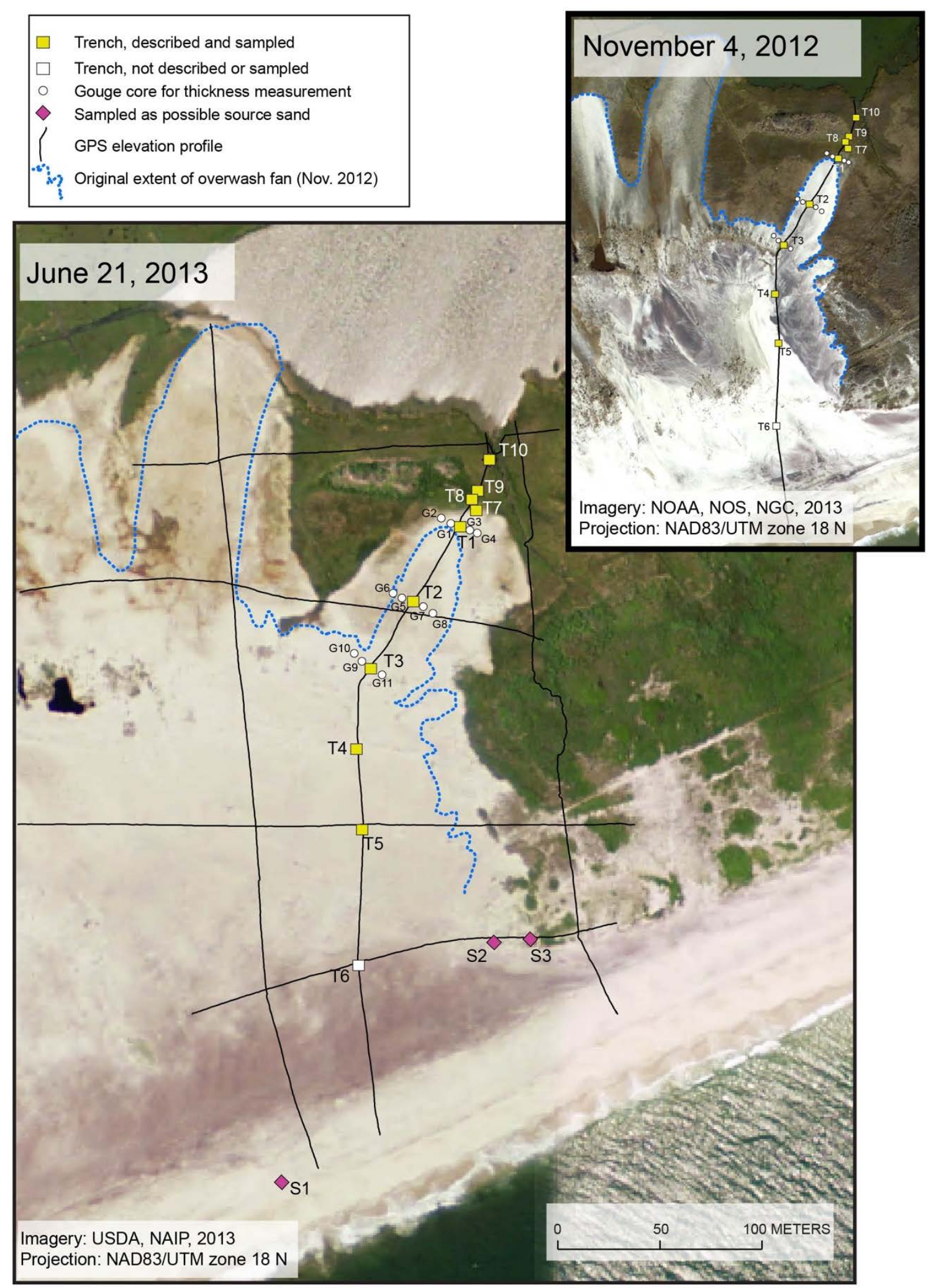

Figure 4. Map/satellite image of the east field site on Fire Island, New York, with sampling locations and Global Positioning System (GPS) transects shown on June 21, 2013, imagery collected almost 7 months after Hurricane Sandy (image downloaded from U.S. Department of Agriculture, National Resources Conservation Service, 2014). Yellow (described and sampled) and white (not described or sampled) boxes are trench locations, white circles are 
gouge-core probe locations, magenta diamonds are surface-sample locations, and black lines are GPS survey transects. The dashed blue line shows the extent of the overwash fan derived from the National Oceanic and Atmospheric Administration (NOAA), National Ocean Service, National Geodetic Survey (2013) image of November 4, 2012 (inset), taken just after Hurricane Sandy.
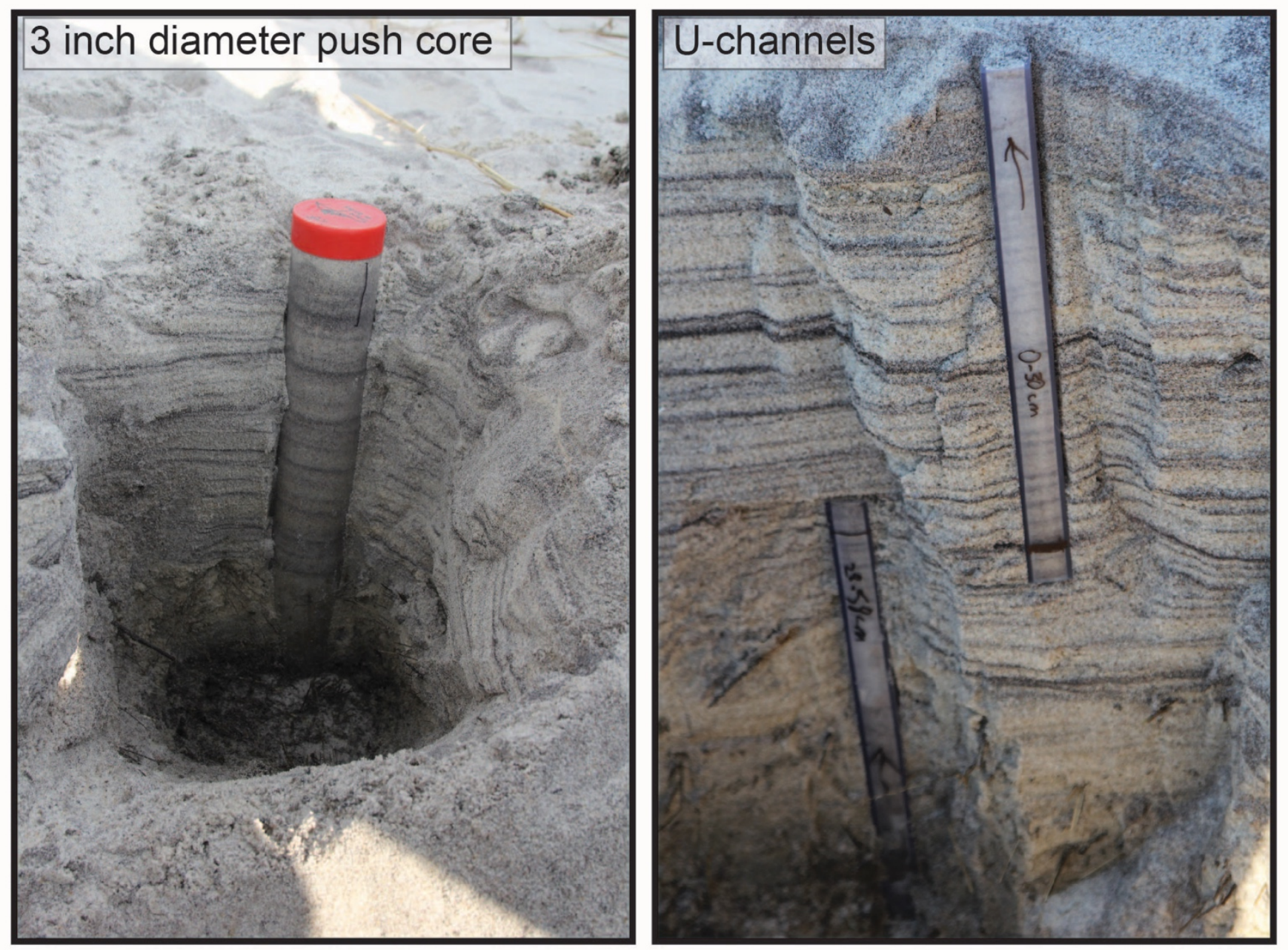

Figure 5. Photographs of push core (left) and U-channel (right) sampling at trench T3 (fig. 4) on Fire Island, New York (U.S. Geological Survey photographs).

At the west field site, one trench was excavated near the inland terminus of the washover deposit (fig. 3). The deposit was sampled with a push core and two U-channels (tables 1 and 2). An additional push core was collected $25 \mathrm{~m}$ west of the trench, and a bulk surface sample was taken $10 \mathrm{~m}$ to the northwest (tables 1 and 3). Grain-size analysis was not performed on samples from the west field site.

\section{X-ray Computed Tomography (CT) Scans}

Push cores from four trenches (T4, T3, T1, and T7) were sent to technicians at the Oregon State University Marine and Geology Repository to make x-ray computed tomographic (CT) density measurements. Scans were acquired at the College of Veterinary Medicine at Oregon State University using a Toshiba Aquilon 64 slice at 120 peak kilovoltage and 200 milliamps, with a pitch of 0.5 seconds (100 milliampere-seconds). Image slices were generated every $2 \mathrm{~mm}$ across the core, with a pixel 
resolution of 500 micrometers $(\mu \mathrm{m})$ in the downcore and across-core directions. The raw DICOM images were processed using OsiriX software.

\section{Grain-Size Analysis}

Grain-size analyses were performed at the USGS Pacific Coastal and Marine Science Center (PCMSC) Sediment and Core Laboratory. In addition to analyzing all of the bulk sediment samples, the lower $22 \mathrm{~cm}$ of core FI13-E4-T3-PC2 was subsampled at $0.2-1.0 \mathrm{~cm}$ intervals to characterize the grainsize distributions of massive and laminated beds. Samples were wet-sieved through $2 \mathrm{~mm}$ and 0.063 $\mathrm{mm}$ sieves and separated as gravel $(>2 \mathrm{~mm})$, sand $(0.063-2 \mathrm{~mm})$, and $\operatorname{mud}(<0.063 \mathrm{~mm})$. The gravel fraction was analyzed by sieving, and the sand and mud fractions were analyzed using a Coulter LS230 laser diffraction particle size analyzer at $1 / 4$-phi $(\varphi)$ size intervals.
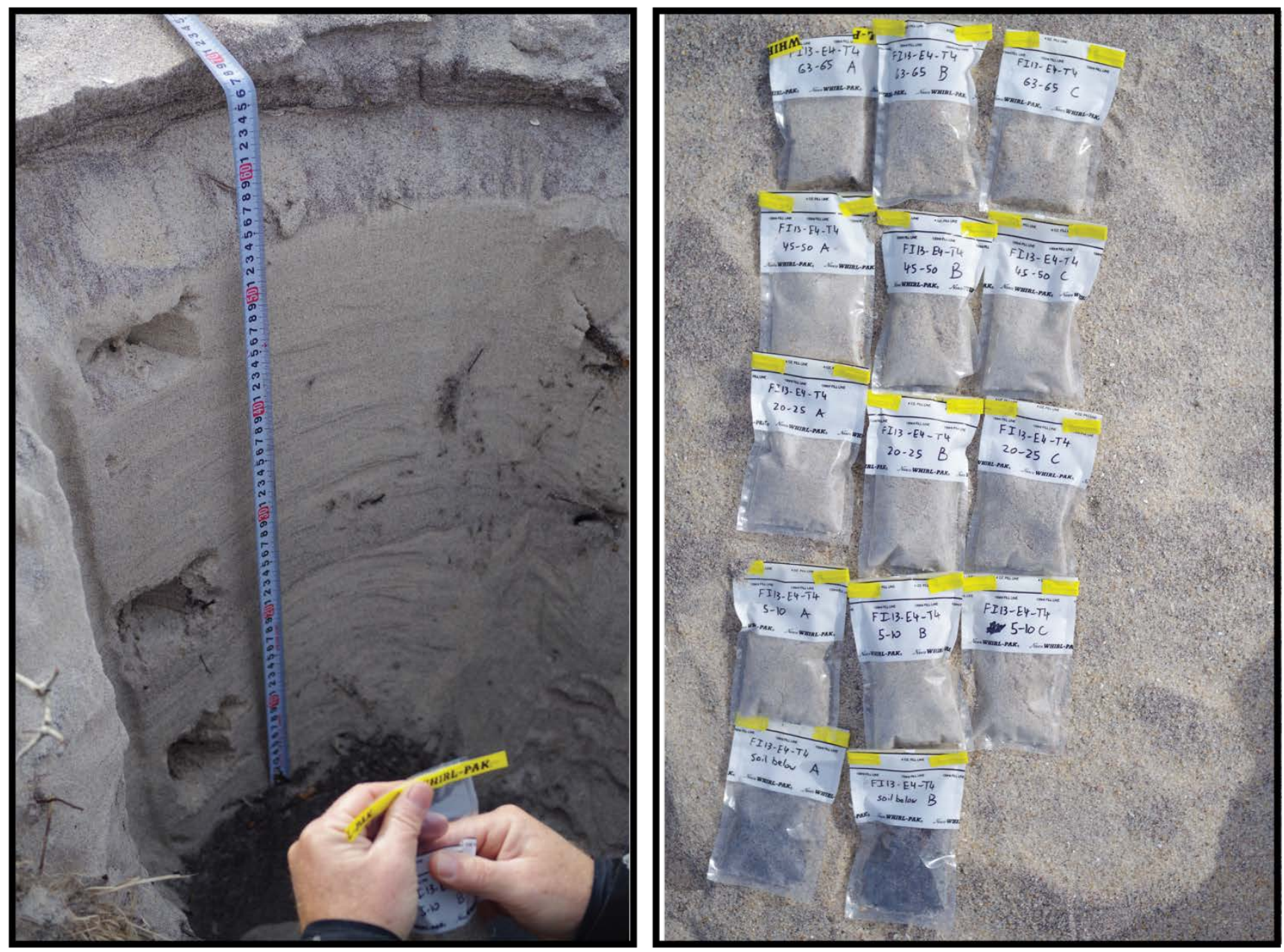

Figure 6. Photographs of collecting bulk sediment samples out of a trench wall (left) and collecting sand samples (right) for grain size and microtextural analyses on Fire Island, New York (U.S. Geological Survey photographs). 
Table 1. Push-core sample inventory from Fire Island, New York.

\begin{tabular}{llcccc}
\hline Trench & Sample ID1 & Latitude & Longitude & $\begin{array}{c}\text { Top, in centimeters } \\
\text { from surface }\end{array}$ & $\begin{array}{c}\text { Bottom, in } \\
\text { centimeters from } \\
\text { surface }\end{array}$ \\
\hline & & \multicolumn{2}{c}{ East field site } \\
\hline T2 & FI13-E4-T2-PC1 & 40.72920 & -72.88127 & 0 & 18 \\
T3 & FI13-E4-T3-PC2 & 40.72892 & -72.88153 & 0 & 50 \\
T4 & FI13-E4-T4-PC3 & 40.72859 & -72.88164 & 0 & 51 \\
T4 & FI13-E4-T4-PC4 & 40.72859 & -72.88164 & 45 & 66 \\
T1 & FI13-E4-T1-PC5 & 40.72954 & -72.88097 & 0 & 20 \\
T7 & FI13-E4-T7-PC6 & 40.72961 & -72.88090 & 0 & 20 \\
T7 & FI13-E4-T7-PC7 & 40.72961 & -72.88090 & 0 & 10 \\
T8 & FI13-E4-T8-PC8 & 40.72966 & -72.88092 & 0 & 15 \\
T9 & FI13-E4-T9-PC9 & 40.72971 & -72.88087 & 0 & 10 \\
T1 & FI13-E4-T1-SLB1 & 40.72955 & -72.88099 & 0 & 30 \\
T1 & FI13-E4-T1-SLB2 & 40.72955 & -72.88099 & 0 & 13 \\
\hline & & & West field site & & 43 \\
\hline T1 & FI13-W-T1-PC10 & 40.64304 & 73.16719 & 28 & 11 \\
T2 & FI13-W-T2-PC11 & 40.64298 & 73.16748 & 0 & \\
\hline
\end{tabular}

Table 2. U-channel sample inventory from Fire Island, New York.

\begin{tabular}{llcccc}
\hline Trench & \multicolumn{1}{c}{ Sample ID } & Latitude & Longitude & $\begin{array}{c}\text { Top, in centimeters } \\
\text { from surface }\end{array}$ & $\begin{array}{c}\text { Bottom, in } \\
\text { centimeters from } \\
\text { surface }\end{array}$ \\
\hline & & \multicolumn{2}{c}{ East field site } \\
\hline T1 & FI13-E4-T1-U1-A & 40.72955 & -72.88099 & 0 & 30 \\
T1 & FI13-E4-T1-U1-B & 40.72955 & -72.88099 & 0 & 28 \\
T2 & FI13-E4-T2-U2 & 40.72920 & -72.88127 & 0 & 25 \\
T3 & FI13-E4-T3-U3-sec1 & 40.72892 & -72.88153 & 0 & 30 \\
T3 & FI13-E4-T3-U3-sec2 & 40.72892 & -72.88153 & 28 & 58 \\
T5 & FI13-E4-T5-U3-sec1 & 40.72822 & -72.88160 & 0 & 20 \\
T5 & FI13-E4-T5-U3-sec2 & 40.72822 & -72.88160 & 15 & 65 \\
T5 & FI13-E4-T5-U3-sec3 & 40.72822 & -72.88160 & 39 & 89 \\
\hline & & West field site & \multicolumn{2}{c}{30} \\
\hline T1 & FI13-W-T1-U4-sec1 & 40.64306 & -73.16719 & 0 & 45 \\
T1 & FI13-W-T1-U4-sec2 & 40.64306 & -73.16719 & 15 & \\
\hline
\end{tabular}


Table 3. Bulk-sediment sample inventory from Fire Island, New York.

\begin{tabular}{|c|c|c|c|c|c|c|}
\hline Trench & Sample ID & Latitude & Longitude & $\begin{array}{c}\text { Top, in } \\
\text { centimeters } \\
\text { from surface }\end{array}$ & $\begin{array}{l}\text { Bottom, in } \\
\text { centimeters } \\
\text { from surface }\end{array}$ & $\begin{array}{l}\text { Additional } \\
\text { Samples }^{1}\end{array}$ \\
\hline \multicolumn{7}{|c|}{ East field site } \\
\hline $\mathrm{T} 1$ & FI13-E4-T1-4-9cm & 40.72954 & -72.88097 & 4 & 9 & MT \\
\hline $\mathrm{T} 1$ & FI13-E4-T1-12-14cm & 40.72954 & -72.88097 & 12 & 14 & MT \\
\hline $\mathrm{T} 1$ & FI13-E4-T1-20-23cm & 40.72954 & -72.88097 & 20 & 23 & MT \\
\hline $\mathrm{T} 1$ & FI13-E4-T1-soil_below & 40.72954 & -72.88097 & 25 & 27 & \\
\hline $\mathrm{T} 2$ & FI13-E4-T2-1-6cm & 40.72921 & -72.88126 & 1 & 6 & MT \\
\hline $\mathrm{T} 2$ & FI13-E4-T2-8-10cm & 40.72921 & -72.88126 & 8 & 10 & MT \\
\hline $\mathrm{T} 2$ & FI13-E4-T2-13-16cm & 40.72921 & -72.88126 & 13 & 16 & MT \\
\hline $\mathrm{T} 2$ & FI13-E4-T2-soil_below & 40.72921 & -72.88126 & 21 & 23 & \\
\hline $\mathrm{T} 3$ & FI13-E4-T3-0-3cm & 40.72894 & -72.88149 & 0 & 3 & MT \\
\hline $\mathrm{T} 3$ & FI13-E4-T3-hvy_mineral_lamina & 40.72894 & -72.88149 & 2 & 36 & \\
\hline $\mathrm{T} 3$ & FI13-E4-T3-8-13cm & 40.72894 & -72.88149 & 8 & 13 & MT \\
\hline $\mathrm{T} 3$ & FI13-E4-T3-28-33cm & 40.72894 & -72.88149 & 28 & 33 & MT \\
\hline $\mathrm{T} 3$ & FI13-E4-T3-43-48cm & 40.72894 & -72.88149 & 43 & 48 & MT \\
\hline $\mathrm{T} 3$ & FI13-E4-T3-soil_below & 40.72894 & -72.88149 & 53 & 55 & \\
\hline $\mathrm{T} 4$ & FI13-E4-T4-0-2cm & 40.72859 & -72.88164 & 0 & 2 & MT \\
\hline $\mathrm{T} 4$ & FI13-E4-T4-15-20cm & 40.72859 & -72.88164 & 15 & 20 & MT \\
\hline $\mathrm{T} 4$ & FI13-E4-T4-40-45cm & 40.72859 & -72.88164 & 40 & 45 & MT \\
\hline $\mathrm{T} 4$ & FI13-E4-T4-55-60cm & 40.72859 & -72.88164 & 55 & 60 & MT \\
\hline $\mathrm{T} 4$ & FI13-E4-T4-soil_below & 40.72859 & -72.88164 & 64 & 66 & \\
\hline T5 & FI13-E4-T5-0-8cm & 40.72822 & -72.88159 & 0 & 8 & MT \\
\hline $\mathrm{T} 5$ & FI13-E4-T5-15-20cm & 40.72822 & -72.88159 & 15 & 20 & MT \\
\hline T5 & FI13-E4-T5-55-60cm & 40.72822 & -72.88159 & 55 & 60 & MT \\
\hline T5 & FI13-E4-T5-85-90cm & 40.72822 & -72.88159 & 85 & 90 & MT \\
\hline T5 & FI13-E4-T5-soil_below & 40.72822 & -72.88159 & 100 & 102 & \\
\hline $\mathrm{T} 7$ & FI13-E4-T7-1-5cm & 40.72960 & -72.88090 & 1 & 5 & MT \\
\hline $\mathrm{T} 7$ & FI13-E4-T7-10-14cm & 40.72960 & -72.88090 & 10 & 14 & MT \\
\hline $\mathrm{T} 7$ & FI13-E4-T7-21-25cm & 40.72960 & -72.88090 & 21 & 25 & MT \\
\hline $\mathrm{T} 7$ & FI13-E4-T7-soil_below & 40.72960 & -72.88090 & 27 & 29 & \\
\hline $\mathrm{T} 8$ & FI13-E4-T8-0-4cm & 40.72966 & -72.88091 & 0 & 4 & MT \\
\hline $\mathrm{T} 8$ & FI13-E4-T8-8-11 cm & 40.72966 & -72.88091 & 8 & 11 & MT \\
\hline $\mathrm{T} 8$ & FI13-E4-T8-soil_below & 40.72966 & -72.88091 & 13 & 15 & \\
\hline T9 & FI13-E4-T9-1-5cm & 40.72970 & -72.88089 & 1 & 5 & MT \\
\hline T9 & FI13-E4-T9-soil_below & 40.72970 & -72.88089 & 6 & 8 & \\
\hline $\begin{array}{l}\text { Beach } \\
\text { surface }\end{array}$ & FI13-E4-s1 & 40.72668 & -72.88210 & 0 & 3 & MT \\
\hline
\end{tabular}




\begin{tabular}{|c|c|c|c|c|c|c|}
\hline Trench & Sample ID & Latitude & Longitude & $\begin{array}{c}\text { Top, in } \\
\text { centimeters } \\
\text { from surface }\end{array}$ & $\begin{array}{l}\text { Bottom, in } \\
\text { centimeters } \\
\text { from surface }\end{array}$ & $\begin{array}{c}\text { Additional } \\
\text { Samples }^{1}\end{array}$ \\
\hline $\begin{array}{l}\text { Accreted } \\
\text { dune } \\
\text { surface }\end{array}$ & FI13-E4-s2 & 40.72769 & -72.88084 & 0 & 3 & MT \\
\hline Old dune & FI13-E4-s3 & 40.72769 & -72.88065 & 50 & 55 & MT \\
\hline $\begin{array}{l}\text { T10 } \\
\text { surface }\end{array}$ & FI13-E4-s4 & 40.72984 & -72.88081 & 0 & 1 & - \\
\hline \multicolumn{7}{|c|}{ West field site } \\
\hline $\begin{array}{c}\text { Overwash } \\
\text { deposit } \\
\text { surface }\end{array}$ & FI13-W-s1 & 40.64306 & -73.16719 & 0 & 1 & - \\
\hline
\end{tabular}

${ }^{1}$ Additional samples from the same layer were collected for microtextural analysis (MT).

Microtextural Analysis

Quartz sand grains can develop microtextural features that may be attributed to a specific transport processes or sedimentary environment (Costa and others, 2012). Microphotographs of grains taken with a scanning electron microscope (SEM) reveal microtextural features such as fresh surfaces, percussion marks, dissolution features, and adhering particles (fig. 7). The proportion of grain surface occupied by each feature was estimated on a scale of 0 to 5 ( 0 to $>75$ percent of the grain surface). Roundness was classified using the Powers scale (Powers, 1953). For each sample, at least 20 grains were evaluated, and median values of the occupied grain surface and roundness were reported. A principal component analysis was conducted on these microtextural features to determine if a dominant type of sediment transport could be distinguished between samples.

\section{DGPS Elevations}

Point and transect elevations were collected using a Differential Global Positioning System (DGPS)-enabled Trimble R7 GNSS Receiver and a Trimble Zephyr Model 2 antenna. All data were collected in Network Real Time Kinematic (RTK) surveys, with corrections received over a cellular network from the KeyNet Continuously Operating Reference Station (CORS) network.

Transects were surveyed with the antenna mounted on a backpack, collecting elevation data at approximately $1-\mathrm{m}$ intervals along each transect. Point elevations at trenches and water-level indicators were obtained with the antenna mounted on a 2-m long survey pole. For the east field site, the main trace of the overwash fan and tongue were profiled in addition to two north-south and four east-west transects (fig. 4). Minimum flow-depth indicators, which were only found in the west field site, were identified as coarse plant litter and trash wrapped around small trees and brush. Elevations of the flowdepth indicators and the ground directly below were measured to determine minimum flow depths and surface elevations at these points (table 4).

Because various factors affect the error of a DGPS, the positional precision can be different at each measured point. Uncertainty in the horizontal and vertical RTK position, as indicated by the 95 th percentile of precision, were generally less than $7 \mathrm{~cm}$ and typically about $3-4 \mathrm{~cm}$ (fig. 8). The rootmean-square error (RMSE), another error metric, in elevation for the DGPS survey was about $5-6 \mathrm{~cm}$, calculated from intersecting points on transect lines. 

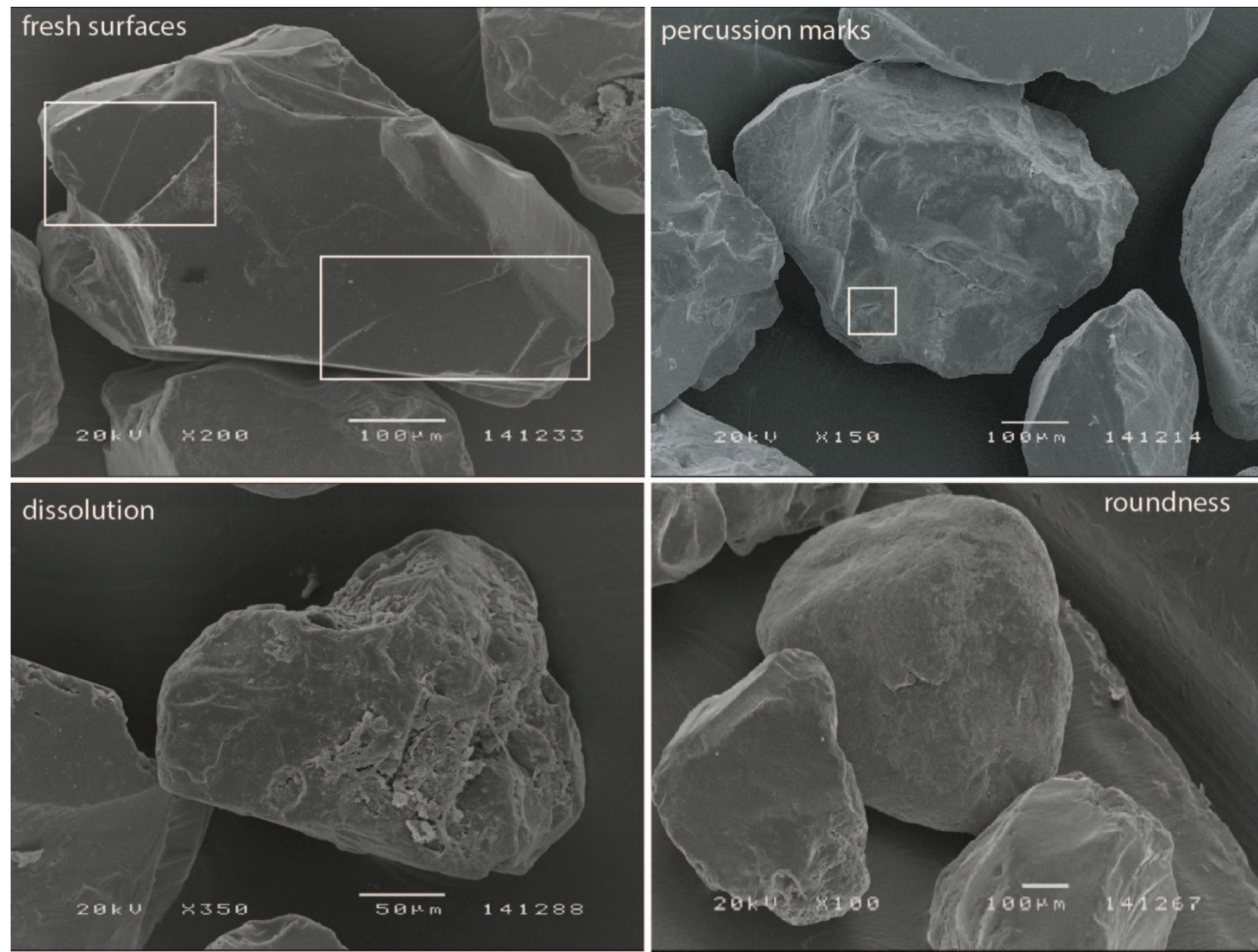

Figure 7. Scanning electron microscope photographs showing microtextural features of quartz grains from Fire Island, New York. um, micrometer. (U.S. Geological Survey photographs.)
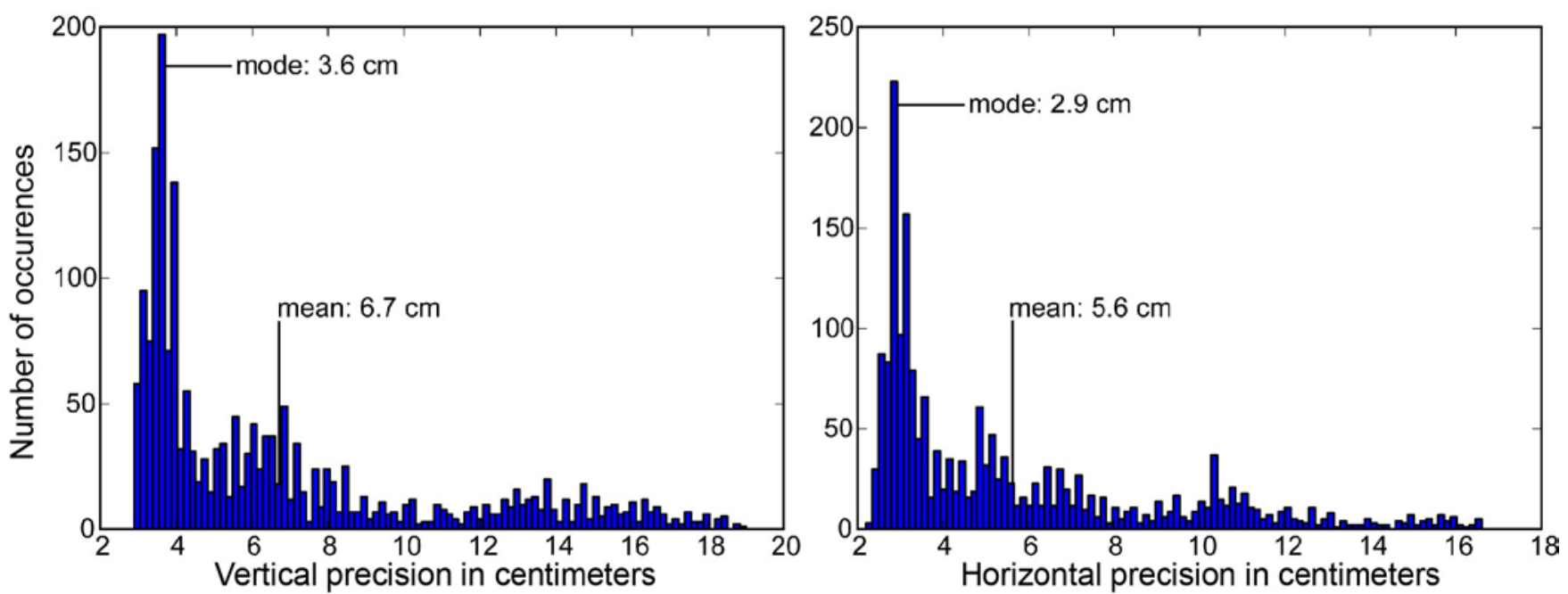

Figure 8. Histograms of the 95th percentile vertical and horizontal precision for the Differential Global Positioning System surveys done on Fire Island, New York. 
Table 4. Surveyed minimum flow depth indicators at the west field site on Fire Island, New York.

\begin{tabular}{llllll}
\hline $\begin{array}{c}\text { location } \\
\text { number }\end{array}$ & Latitude & Longitude & $\begin{array}{c}\text { Flow marker elevation, } \\
\text { in meters above } \\
\text { NAVD88 }\end{array}$ & $\begin{array}{c}\text { Ground elevation, } \\
\text { in meters above } \\
\text { NAVD88 }\end{array}$ & $\begin{array}{c}\text { Minimum flow } \\
\text { depth, meters }\end{array}$ \\
\hline 13 & 40.64303 & -72.16728 & 2.03 & 1.31 & 0.72 \\
14 & 40.64300 & -72.16735 & 1.88 & 1.31 & 0.57 \\
17 & 40.64298 & -72.16741 & 1.75 & 1.27 & 0.49 \\
18 & 40.64298 & -72.16742 & 1.74 & 1.18 & 0.56 \\
21 & 40.64300 & -72.16750 & 1.86 & 1.36 & 0.50 \\
26 & 40.64293 & -72.16774 & 1.50 & 1.08 & 0.42 \\
\hline
\end{tabular}

\section{Lidar Data}

The deposit thicknesses measured in the field in November 2013 do not necessarily reflect the deposit thicknesses immediately after deposition, largely because of eolian reworking of the deposit in the year following the Hurricane Sandy. NPS volunteers compiled a comprehensive dataset of deposit thicknesses across Fire Island following the storm (Hapke and others, 2013), but most measurements were taken near the edge of overwash fans. To reconstruct the original deposit thickness of the fan in the east field site, the bare-earth surfaces derived from pre-storm (January 20, 2012) and post-storm (November 5, 2012) lidar surveys were differenced, showing regions of net erosion or deposition (fig. 9). The root mean square error (RMSE) reported for the lidar surveys are $9 \mathrm{~cm}$ for the pre-storm dataset (National Oceanic and Atmospheric Administration, National Ocean Service, Office for Coastal Management, 2012) and $7.5 \mathrm{~cm}$ for the post-storm dataset (Stockdon and others, 2013), with a combined RMSE of $16.5 \mathrm{~cm}$.

Because of reworking in the year following deposition, the thickness of the original deposit could not be measured to test the accuracy of the thicknesses estimated from lidar. However, by differencing the pre-Sandy lidar and DGPS elevations measured on the trench transect, the deposit thickness could be predicted and then compared to measured deposit thicknesses (fig. 10). Measured and predicted thicknesses were within $8 \mathrm{~cm}$ of each other at 17 of 20 locations, but at 3 locations (T5, T7, and G1) the predicted thicknesses were 18.5, 21.7, and $23.8 \mathrm{~cm}$, respectively, less than the measured thicknesses (fig. 11). There were also two sites (T9 and T10) where thin deposits were measured (6 and $1 \mathrm{~cm}$, respectively) and the predicted thicknesses were negative. The RMSE between the predicted and measured thicknesses is $9.5 \mathrm{~cm}$. On the basis of the positive correlation between the two methods of determining thickness at this particular field site, it appears that differencing the pre-Sandy lidar surface with the post-Sandy DGPS elevations on the overwash fan provides a reasonable estimate of the Sandy deposit thickness at most of the trenches. However, the RMSE of $9.5 \mathrm{~cm}$ and large discrepancies at T5, T7, and G1 suggest that an overwash volume calculation using lidar and DGPS datasets would contain large uncertainties. 


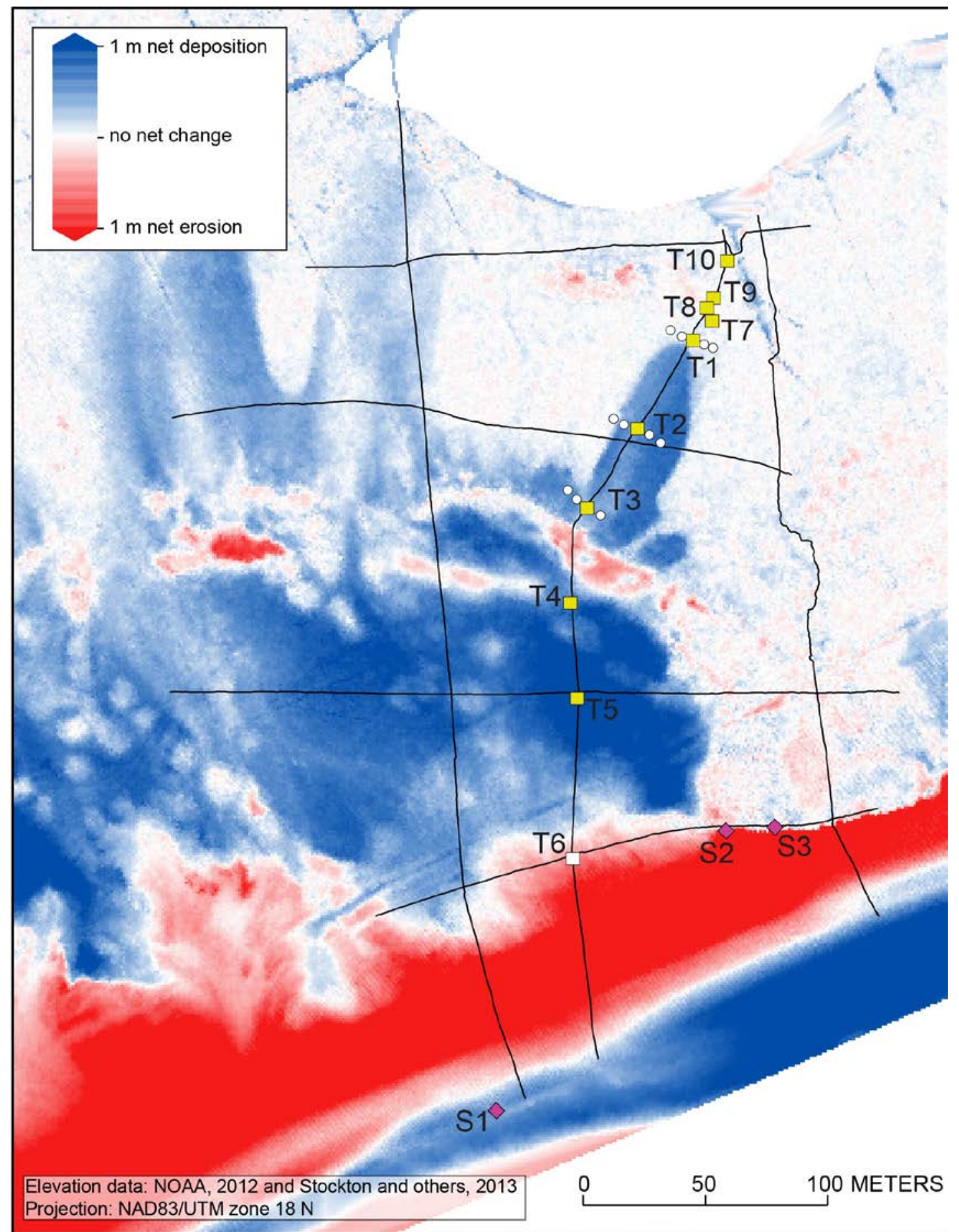

Figure 9. Map showing deposition and erosion inferred from differencing pre- and post-Hurricane Sandy lidar data from Fire Island, New York. Yellow boxes are trench locations, white circles are gouge-core probe locations, magenta diamonds are surface-sample locations, and black lines are Global Positioning System (GPS) survey transects. m, meter. 


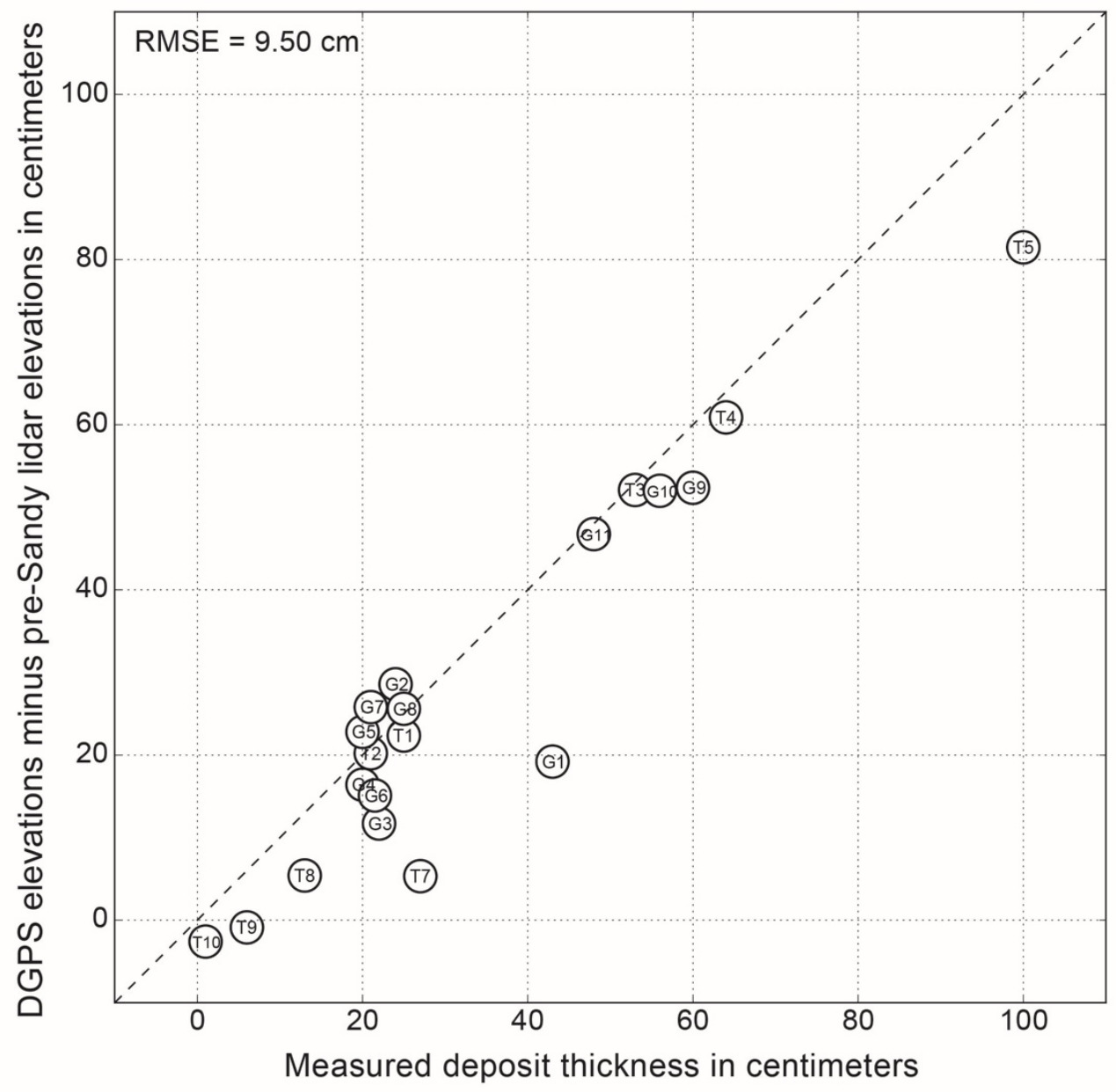

Figure 10. Graph showing measured versus inferred (from Differential Global Positioning System, pre-Hurricane Sandy lidar elevations) sediment-deposit thicknesses from Fire Island, New York. Labeled circles are trench sites shown on figure 4. RMSE, root-mean-square error; cm, centimeter. 

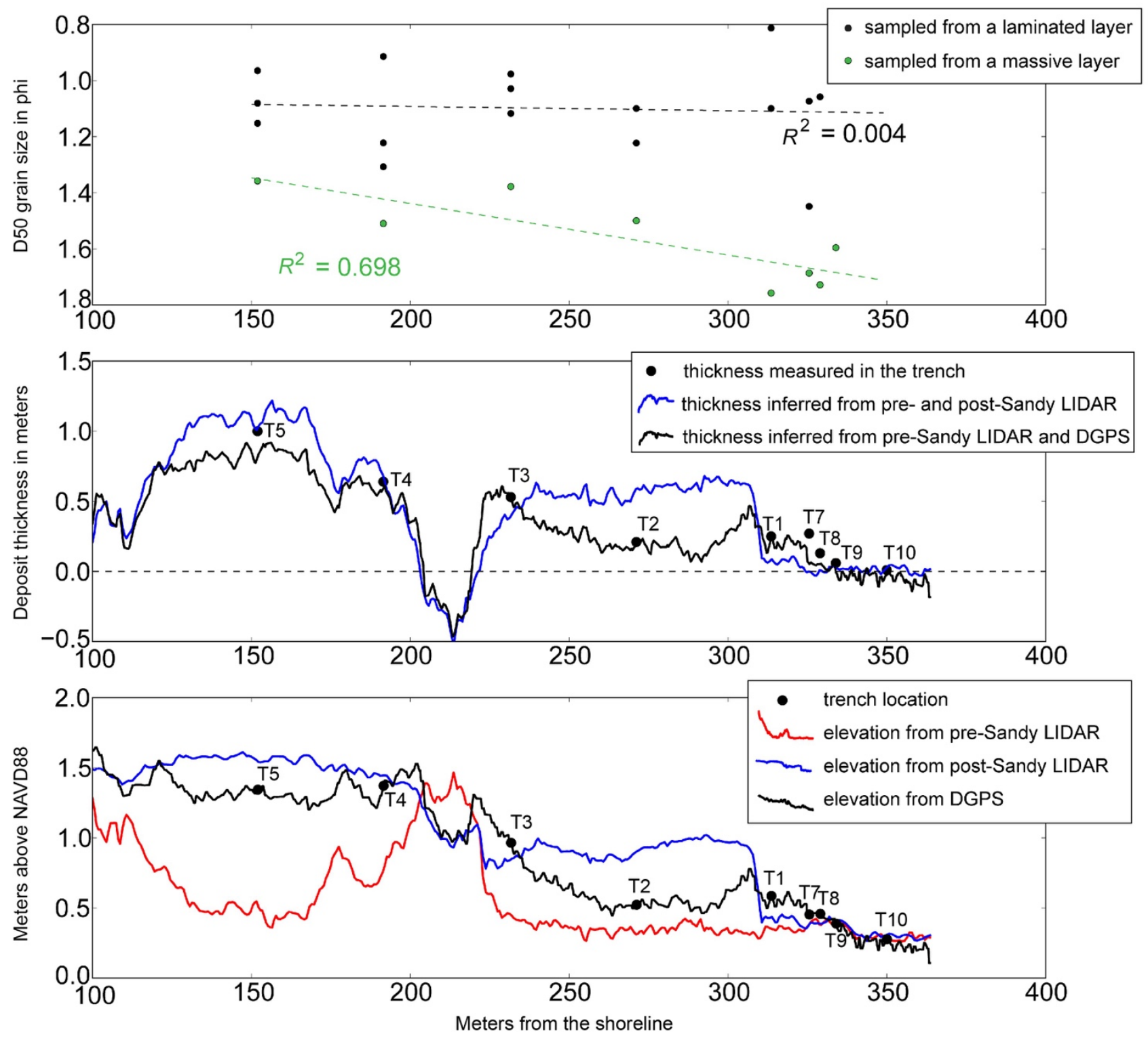

Figure 11. Graphs showing median grain size (D50) (top), deposit thickness (middle), and surface elevation (bottom) as a function of distance from shore along the east field site transect (fig. 2) on Fire Island, New York. $m$, meters; $\varphi$, phi; $R^{2}$, coefficient of determination. 


\section{Results}

\section{Washover Thickness}

Deposit thickness measured in trenches at the east field site range from $1 \mathrm{~m}$ in the trench nearest to shore ( $150 \mathrm{~m}$ inland) to $1 \mathrm{~cm}$ in the back-barrier marsh (350 $\mathrm{m}$ inland) (fig. 11). Along the washover terrace (T5, T4, and T3), the thickness decreases from $1 \mathrm{~m}$ to about $50 \mathrm{~cm}$. On the washover fan (T2, $\mathrm{T} 1$, and T7), thicknesses vary from 20 to $25 \mathrm{~cm}$. The locations of trenches $\mathrm{T} 1$ and $\mathrm{T} 7$ were not on the overwash fan immediately post-Sandy but were at the edge of the reworked fan when observed in November, 2013 (figs. 4 and 11). Therefore, the deposits at T1, T7, and further lagoon-ward at T9 and T10 may have formed entirely by post-Sandy processes, most likely by eolian transport. The deposit rapidly thins from 25 to $13 \mathrm{~cm}$ between $\mathrm{T} 7$ and $\mathrm{T} 8$, marked by a transition on the surface from bare sand to marsh grass. A few meters further into the marsh, the sand is only $6 \mathrm{~cm}$ thick at T9. The furthest lagoonward trench, T10, exhibited 2-4 mm of mud at the surface, overlying a $1 \mathrm{~cm}$ sandy layer.

The thicknesses inferred from lidar show that the washover terrace and washover fan represent two areas of deposition, which are separated by a small depression located between T4 and T3 (fig. 11). This depression is currently bounded on either side by small dunes anchored by clumps of dune grass. The pre-Sandy lidar elevations show that the peak of a 1-m-high ridge used to be in the location of the depression and that the upper $40 \mathrm{~cm}$ of this ridge was eroded during the storm. The previously low-lying areas on either side of the eroded ridge are now filled in by the washover terrace and fan. The washover terrace had a convex-up shape, and was as much as $120 \mathrm{~cm}$ thick at its apex (near T5) and thinned out over $50 \mathrm{~m}$ horizontally in either direction along the transect. The washover fan had a relatively flat surface and was approximately $60 \mathrm{~cm}$ thick, with a steep terminus (angle of repose) at the inland edge. Both the measured thickness and the DGPS and pre-Sandy lidar profile show that the Hurricane Sandy deposit was significantly modified in the year following the storm. The upper 10-20 cm of the washover-terrace deposit and the upper $40 \mathrm{~cm}$ at T2 of the washover-fan deposit have been lost. Beyond the edge of the original washover fan, a sheet of sand gradually thins out over $20 \mathrm{~m}$.

\section{Deposit Characteristics}

The Hurricane Sandy deposit on the washover terrace (T5, T4, and T3) consists of layers of laminated and massive sand (figs. 12-14) overlying a sandy or rooty peat. The uppermost layer (3-5 $\mathrm{cm}$ ) in each trench is composed of loose quartz sand that does not exhibit any structure and cannot hold a face beyond the angle of repose, which we interpret to be reworked eolian sediments. Below this reworked layer in T5 and T4, a 1-3 cm thick laminaset containing subhorizontal, heavy-mineral laminae overlies a massive, sandy layer with roots and woody debris.

All three trenches feature thick $(35-45 \mathrm{~cm})$ laminated beds. Laminae in T5 and T4 are about 1 $\mathrm{mm}$ thick, but lamina thickness in T3 varies from 2 to $20 \mathrm{~mm}$. From bottom to top, laminae in T5 and T3 transition from horizontal to subhorizontal, whereas the opposite trend is observed in T4. Below this laminated layer is a massive or weakly laminated 10-20 cm thick bed of herbaceous and woody debris that overlie the pre-Sandy surface. 

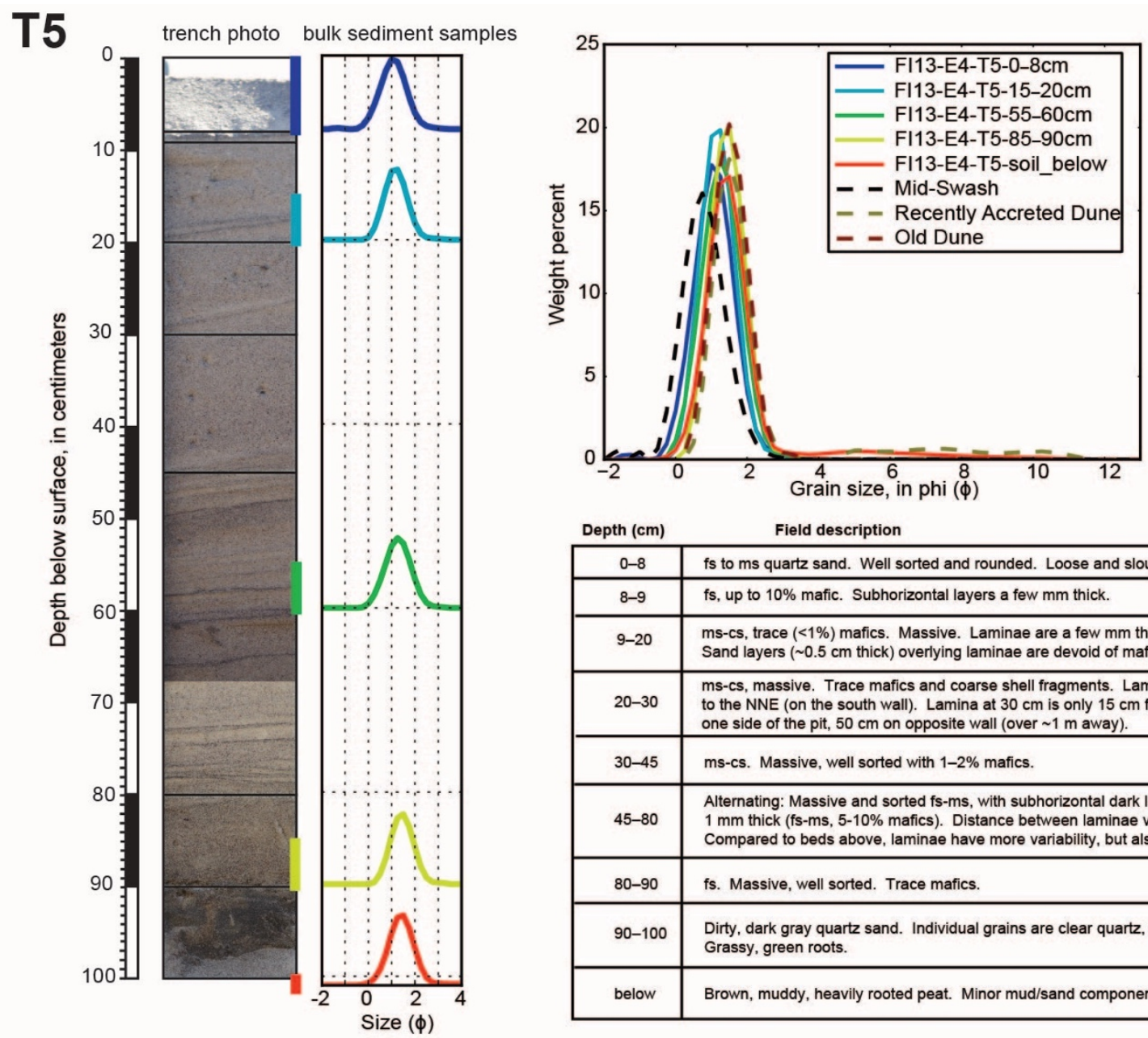

\begin{tabular}{|c|c|}
\hline Depth (cm) & Field description \\
\hline $0-8$ & fs to ms quartz sand. Well sorted and rounded. Loose and sloughing \\
\hline $8-9$ & fs, up to $10 \%$ mafic. Subhorizontal layers a few mm thick. \\
\hline $9-20$ & $\begin{array}{l}\mathrm{ms}-\mathrm{cs} \text {, trace }(<1 \%) \text { mafics. Massive. Laminae are a few mm thick from } 18-20 \mathrm{~cm} \text {. } \\
\text { Sand layers }(\sim 0.5 \mathrm{~cm} \text { thick) overlying laminae are devoid of mafics. }\end{array}$ \\
\hline $20-30$ & $\begin{array}{l}\text { ms-cs, massive. Trace mafics and coarse shell fragments. Lamina are tilted } \sim 15-20^{\circ} \\
\text { to the NNE (on the south wall). Lamina at } 30 \mathrm{~cm} \text { is only } 15 \mathrm{~cm} \text { fromt he surface on } \\
\text { one side of the pit, } 50 \mathrm{~cm} \text { on opposite wall (over } \sim 1 \mathrm{~m} \text { away). }\end{array}$ \\
\hline $30-45$ & ms-cs. Massive, well sorted with $1-2 \%$ mafics. \\
\hline $45-80$ & $\begin{array}{l}\text { Alternating: Massive and sorted fs-ms, with subhorizontal dark lamina about } \\
1 \mathrm{~mm} \text { thick (fs-ms, } 5-10 \% \text { mafics). Distance between laminae varies from } 0.5-4 \mathrm{~cm} \text {. } \\
\text { Compared to beds above, laminae have more variability, but also a lower angle of tilt. }\end{array}$ \\
\hline $80-90$ & fs. Massive, well sorted. Trace mafics. \\
\hline $90-100$ & $\begin{array}{l}\text { Dirty, dark gray quartz sand. Individual grains are clear quartz, stained gray. } \\
\text { Grassy, green roots. }\end{array}$ \\
\hline below & Brown, muddy, heavily rooted peat. Minor mud/sand component \\
\hline
\end{tabular}

Figure 12. Diagram showing trench photograph, grain-size distributions for bulk sediment samples, graph comparing grain-size distributions, and table with stratigraphic description for trench T5 on Fire Island, New York. Layers in the photomosaiced trench photograph are delineated by black lines. Depths and a description for each layer are included in the table. The depths sampled are marked by the colored bar on the photomosaic. The graph shows the grain-size distributions stacked on top of one another (solid lines) compared to samples of possible sources (dashed lines). \%, percent; $m$, meter; $c m$, centimeter; mm, millimeter; $\varphi$, phi. Sediment abbreviations: si, silt; vfs, very fine sand; fs, fine sand; ms, medium sand; cs, coarse sand; vcs, very coarse sand; qtz, quartz. 

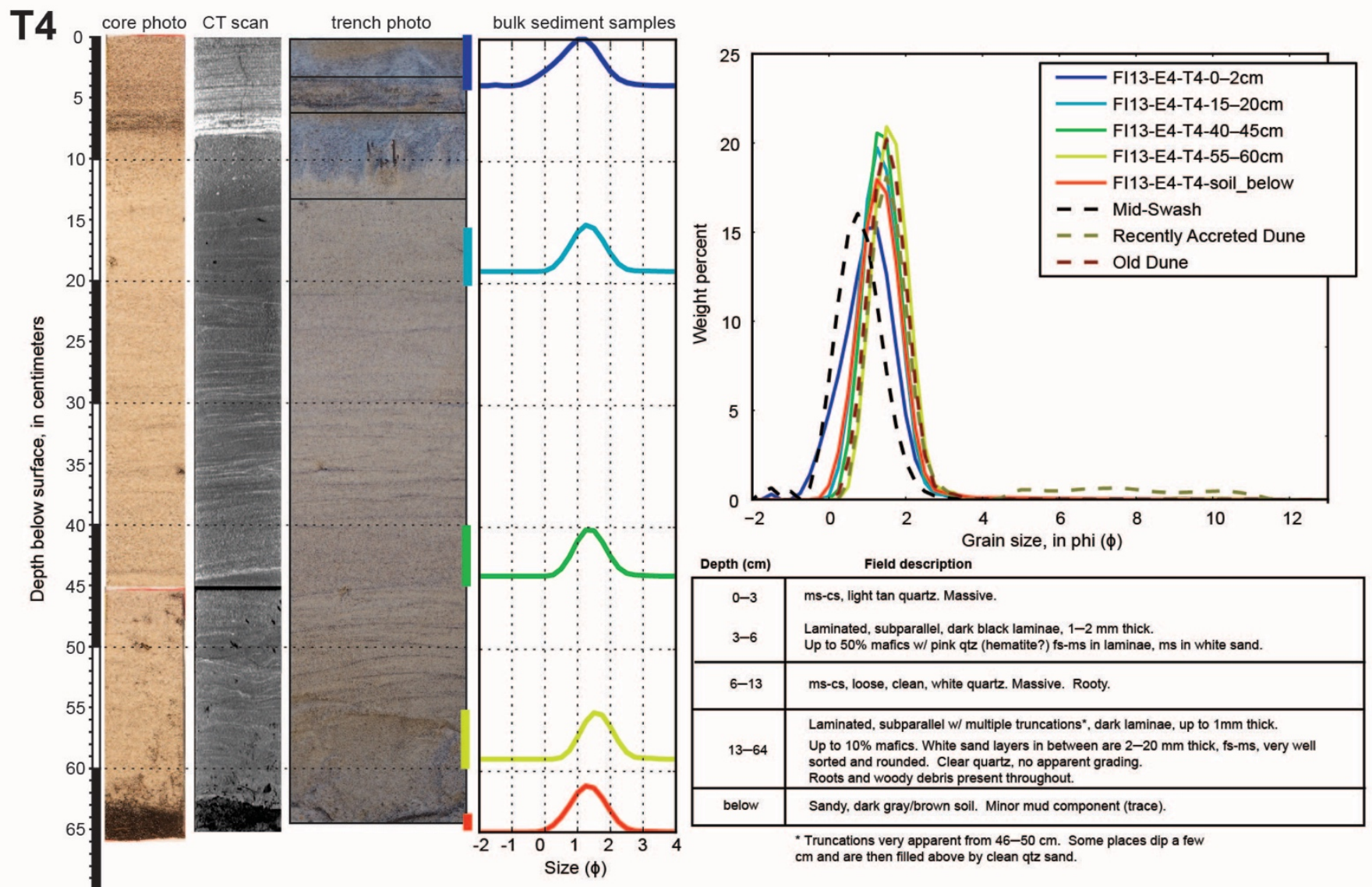

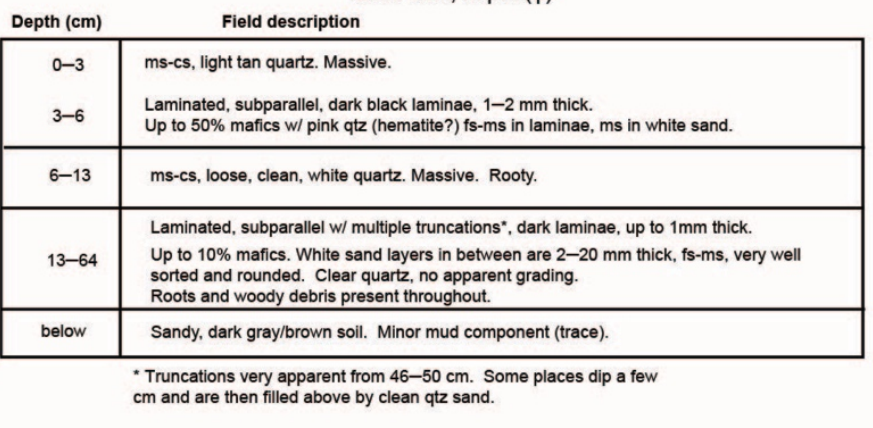

Figure 13. Diagram showing core photograph, $x$-ray computed tomography (CT) scan, trench photograph, grainsize distributions for bulk sediment samples, graph comparing grain-size distributions, and table with stratigraphic description for trench T4 on Fire Island, New York. Layers in the photomosaiced trench photograph are delineated by black lines. Depths and a description for each layer are included in the table. The depths sampled are marked by the colored bar on the photomosaic. The graph shows the grain-size distributions stacked on top of one another (solid lines) compared to samples of possible sources (dashed lines). See figure 12 for explanation of abbreviations. 


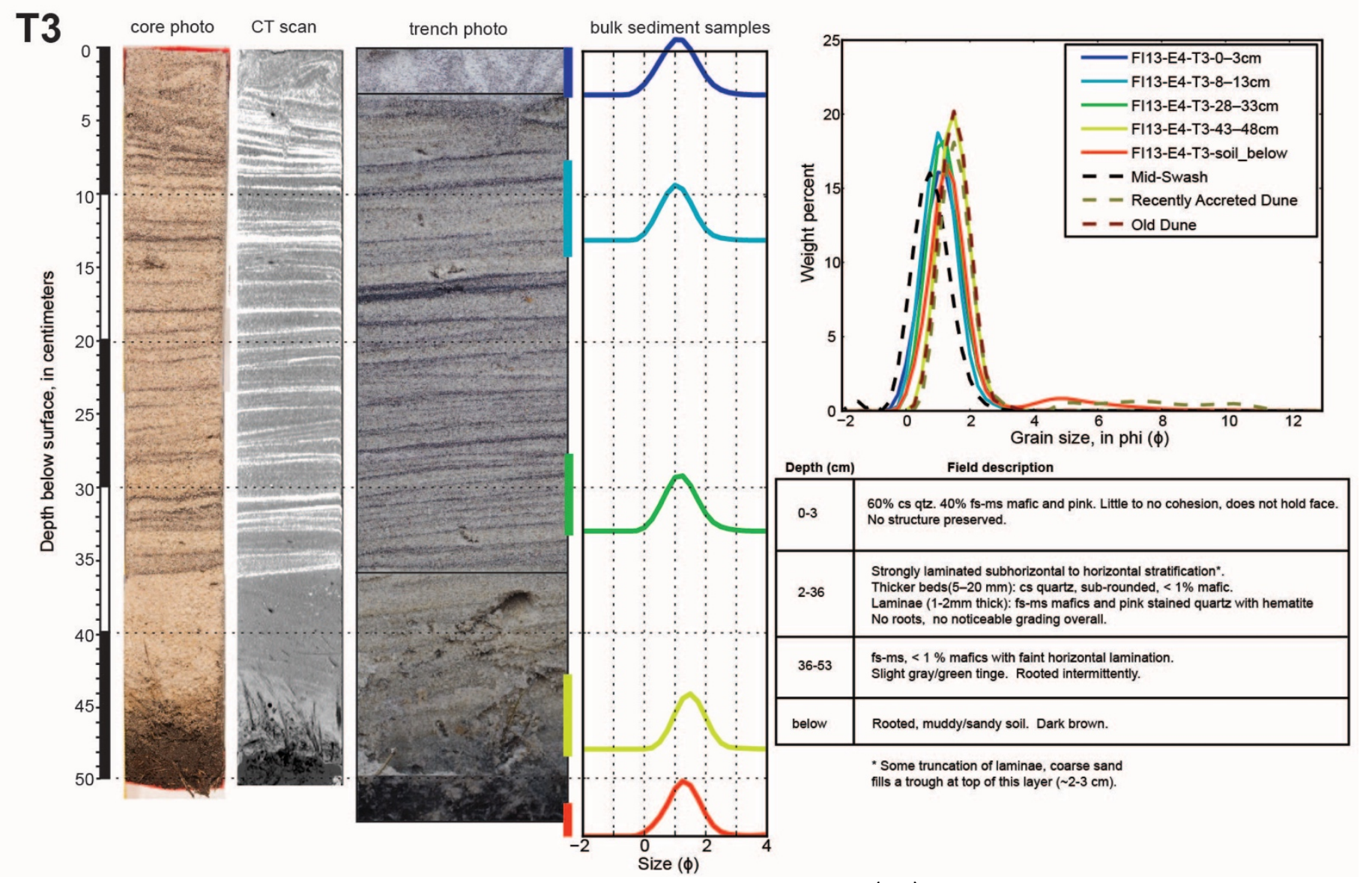

Figure 14. Diagram showing core photograph, $x$-ray computed tomography (CT) scan, trench photograph, grainsize distributions for bulk sediment samples, graph comparing grain-size distributions, and table with stratigraphic description for trench T3 on Fire Island, New York. Layers in the photomosaiced trench photograph are delineated by black lines. Depths and a description for each layer are included in the table. The depths sampled are marked by the colored bar on the photomosaic. The graph shows the grain-size distributions stacked on top of one another (solid lines) compared to samples of possible sources (dashed lines). See figure 12 for explanation of abbreviations.

Finely laminated layers were not observed at trench $\mathrm{T} 2$, nor in trenches beyond the original washover fan extent (T1, T7-T9). T2 and T1 both exhibit faint, wispy laminae in the uppermost $10 \mathrm{~cm}$ (figs. 15 and 16). The lowermost $8 \mathrm{~cm}$ in T2 and T1 is composed of quartz grains coated with a distinct dark-gray stain, making it difficult to identify heavy mineral laminations if they exist. The upper layers of T1 and T7 (13 and $7 \mathrm{~cm}$, respectively) grade from about 1 percent mafics at the surface to around 5 percent at the bottom (figs. 16 and 17). The rest of T7 and all of the deposit in T8 and T9 is rooty and discolored (figs. 17-19). 

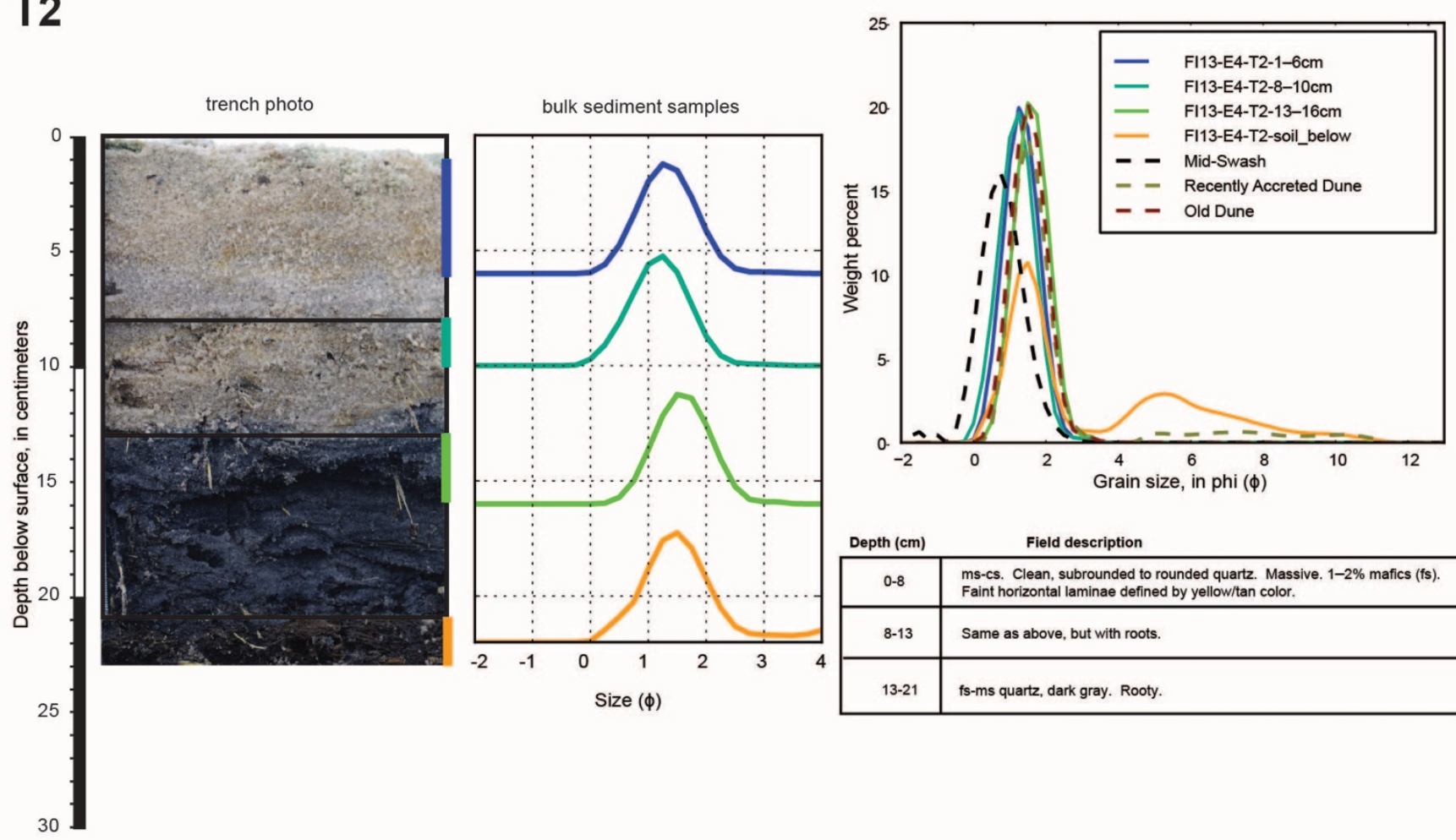

Depth $(\mathrm{cm})$
\begin{tabular}{|c|l|}
\hline $0-8$ & $\begin{array}{l}\text { ms-cs. Clean, subrounded to rounded quartz. Massive. 1-2\% mafics (fs). } \\
\text { Faint horizontal laminae defined by yellow/tan color. }\end{array}$ \\
\hline $8-13$ & Same as above, but with roots. \\
\hline $13-21$ & fs-ms quartz, dark gray. Rooty. \\
\hline
\end{tabular}

Figure 15. Diagram showing trench photograph, grain-size distributions for bulk sediment samples, graph comparing grain-size distributions, and table with stratigraphic description for trench T2 on Fire Island, New York. Layers in the photomosaiced trench photograph are delineated by black lines. Depths and a description for each layer are included in the table. The depths sampled are marked by the colored bar on the photomosaic. The graph shows the grain-size distributions stacked on top of one another (solid lines) compared to samples of possible sources (dashed lines). See figure 12 for explanation of abbreviations. 

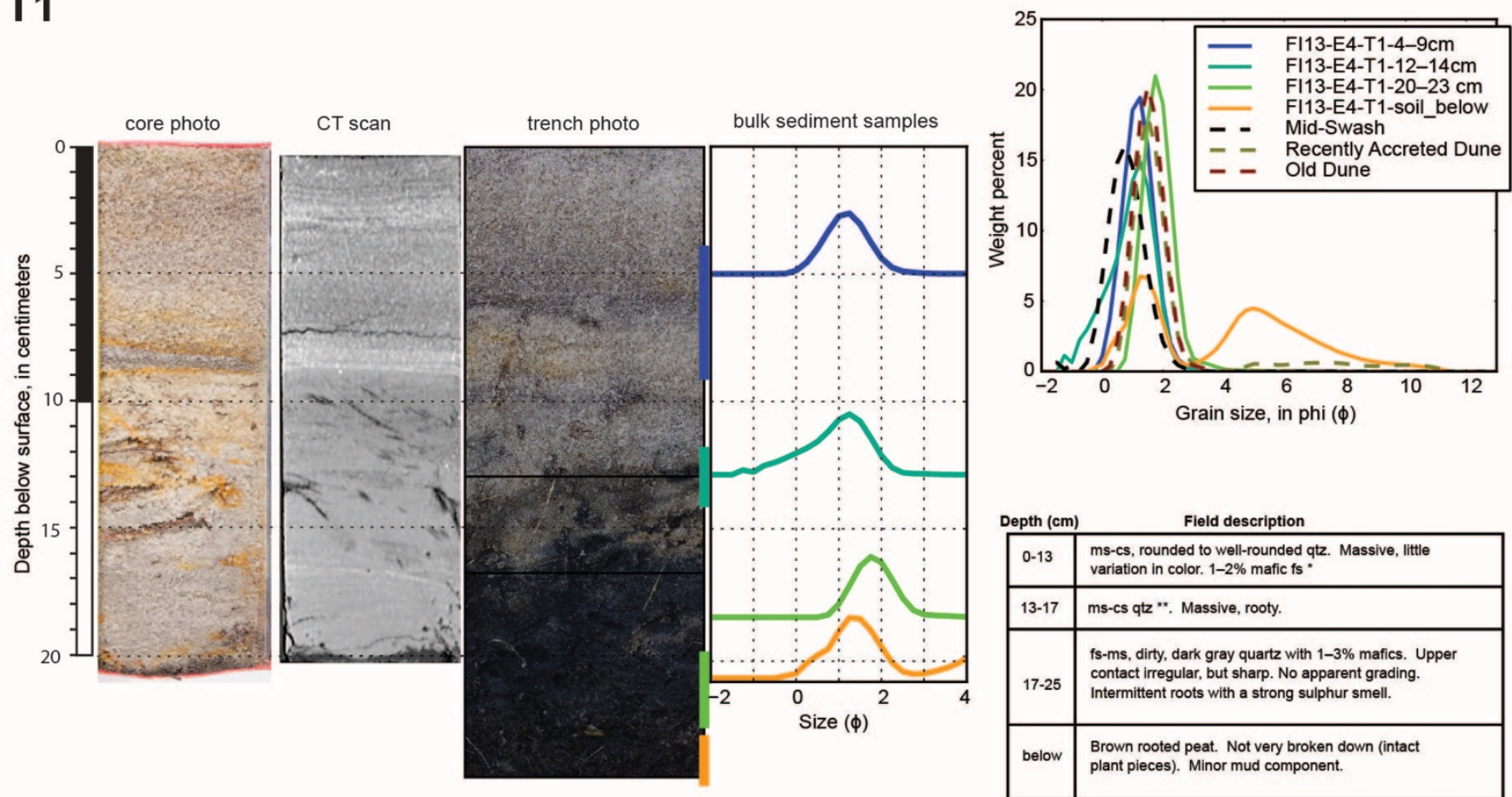

Depth (cm)
\begin{tabular}{|l|l|}
\hline $0-13$ & $\begin{array}{l}\text { ms-cs, rounded to well-rounded qtz. Massive, little } \\
\text { variation in color. 1-2\% mafic fs * }\end{array}$ \\
\hline $13-17$ & ms-cs qtz **. Massive, rooty. \\
\hline $17-25$ & $\begin{array}{l}\text { fs-ms, dirty, dark gray quartz with 1-3\% mafics. Upper } \\
\text { contact irregular, but sharp. No apparent grading. } \\
\text { Intermittent roots with a strong sulphur smell. }\end{array}$ \\
\hline below & $\begin{array}{l}\text { Brown rooted peat. Not very broken down (intact } \\
\text { plant pieces). Minor mud component. }\end{array}$ \\
\hline
\end{tabular}

*A couple of wispy gray layers $0.5-1 \mathrm{~cm}$ thick, with 4- 5\% mafics. Quartz appears slightly finer compared to rest of

the layer. has sharp contacts where visible.

Figure 16. Diagram showing core photograph, $x$-ray computed tomography (CT) scan, trench photograph, grainsize distributions for bulk sediment samples, graph comparing grain-size distributions, and table with stratigraphic description for trench T1 on Fire Island, New York. Layers in the photomosaiced trench photograph are delineated by black lines. Depths and a description for each layer are included in the table. The depths sampled are marked by the colored bar on the photomosaic. The graph shows the grain-size distributions stacked on top of one another (solid lines) compared to samples of possible sources (dashed lines). See figure 12 for explanation of abbreviations. 


\section{T7}
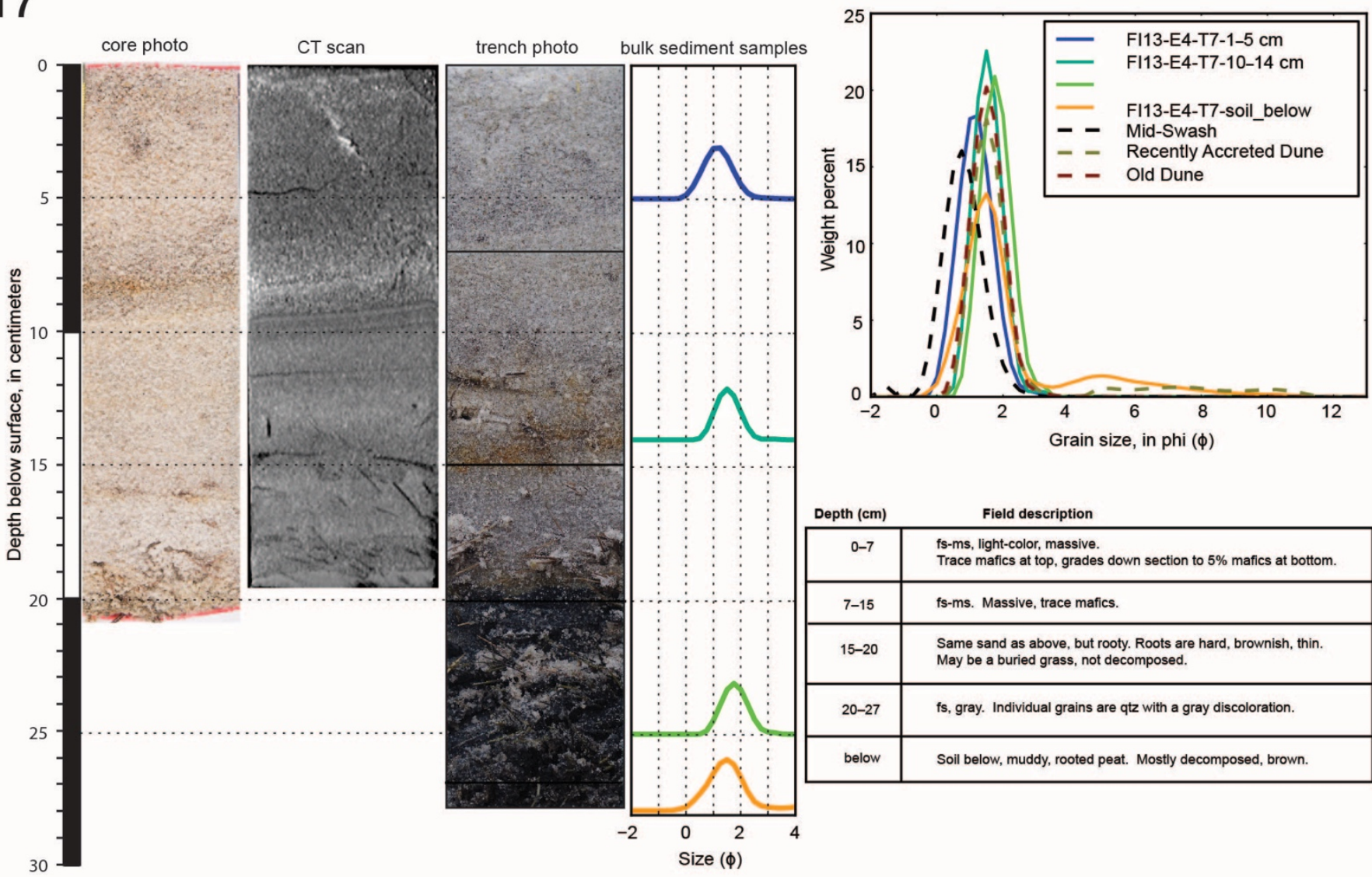

Depth $(\mathrm{cm}) \quad$ Field description

\begin{tabular}{|c|l|}
\hline $0-7$ & $\begin{array}{l}\text { fs-ms, light-color, massive. } \\
\text { Trace mafics at top, grades down section to 5\% mafics at bottom. }\end{array}$ \\
\hline $7-15$ & fs-ms. Massive, trace mafics. \\
\hline $15-20$ & $\begin{array}{l}\text { Same sand as above, but rooty. Roots are hard, brownish, thin. } \\
\text { May be a buried grass, not decomposed. }\end{array}$ \\
\hline $20-27$ & fs, gray. Individual grains are qtz with a gray discoloration. \\
\hline below & Soil below, muddy, rooted peat. Mostly decomposed, brown. \\
\hline
\end{tabular}

Figure 17. Diagram showing core photograph, x-ray computed tomography (CT) scan, trench photograph, grainsize distributions for bulk sediment samples, graph comparing grain-size distributions, and table with stratigraphic description for trench $\mathrm{T7}$ on Fire Island, New York. Layers in the photomosaiced trench photograph are delineated by black lines. Depths and a description for each layer are included in the table. The depths sampled are marked by the colored bar on the photomosaic. The graph shows the grain-size distributions stacked on top of one another (solid lines) compared to samples of possible sources (dashed lines). See figure 12 for explanation of abbreviations. 

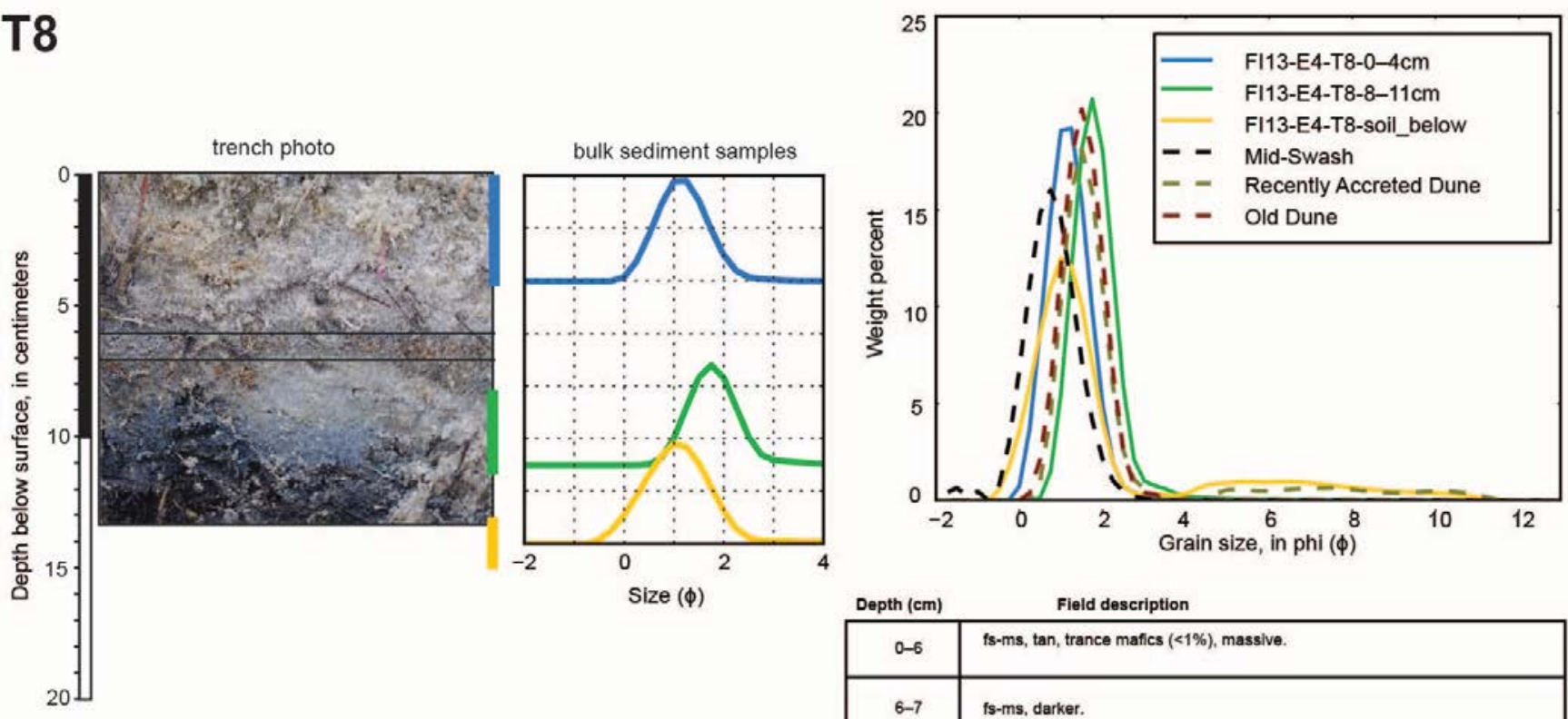

Depth (cm)
\begin{tabular}{|c|l|}
\hline $0-6$ & Field description \\
\hline $6-7$ & fs-ms, tan, trance mafics (<1\%), massive. \\
\hline $7-13$ & vts, gray. \\
\hline below & $\begin{array}{l}\text { Muddy, dark brown peat w/ trace sand. } \\
\text { More decomposed than peat at sites on the fan. }\end{array}$ \\
\hline
\end{tabular}

Figure 18. Diagram showing trench photograph, grain-size distributions for bulk sediment samples, graph comparing grain-size distributions, and table with stratigraphic description for trench T8 on Fire Island, New York. Layers in the photomosaiced trench photograph are delineated by black lines. Depths and a description for each layer are included in the table. The depths sampled are marked by the colored bar on the photomosaic. The graph shows the grain-size distributions stacked on top of one another (solid lines) compared to samples of possible sources (dashed lines). See figure 12 for explanation of abbreviations.

Overall the Hurricane Sandy washover deposits consist of very well sorted, fine to coarse sand with a unimodal grain size distribution (figs. 12-19). The soils beneath the pre-Sandy surface have a bimodal distribution with a silt-clay tail. The dune is very well sorted, medium sand, although the recently accreted part of the dune has a small silt-clay component. The swash-zone surface sample is medium to coarse sand. The lowermost, massive sand in T5, T4, T3, and T2 is a well sorted, medium sand, with very similar grain-size distributions to the "old" dune sample, suggesting that erosion of the dune in the early stages of overwash was the primary source of sediment for the washover fan. Heavy minerals sampled from multiple laminae in T3 (fig. 20) are finer (fine to medium sand) and poorly sorted in comparison to the surrounding beds that consist primarily of quartz grains.

Grain-size distributions from the trench wall bulk sediment samples suggest that there is slight upward coarsening throughout the deposit. The mode in shallower layers is typically around $1 \varphi$, whereas the lower, massive layers have modes between 1.5 and $2 \varphi$. The laminated layers do not exhibit an inland fining trend, but the lower, massive layer generally fines inland (fig. 11), assuming that the sediments in T1, T7, T8, and T9 represent the grain size near the inland end of the washover fan.

The grain-size distributions from detailed subsampling of a core from the lower part of T3 (fig. 20) exhibit a general coarsening upward trend in the lower, massive bed $(36-47 \mathrm{~cm})$, with fine to medium sand at the bottom and medium to coarse sand at the top. However, there are also short fining upward shifts within this coarsening upward trend; for example, between 38.5 and $40.5 \mathrm{~cm}$. In the laminated beds above, the grain-size distributions swing between fine to medium sand within heavy mineral lamina and medium sand in the quartz lamina. 


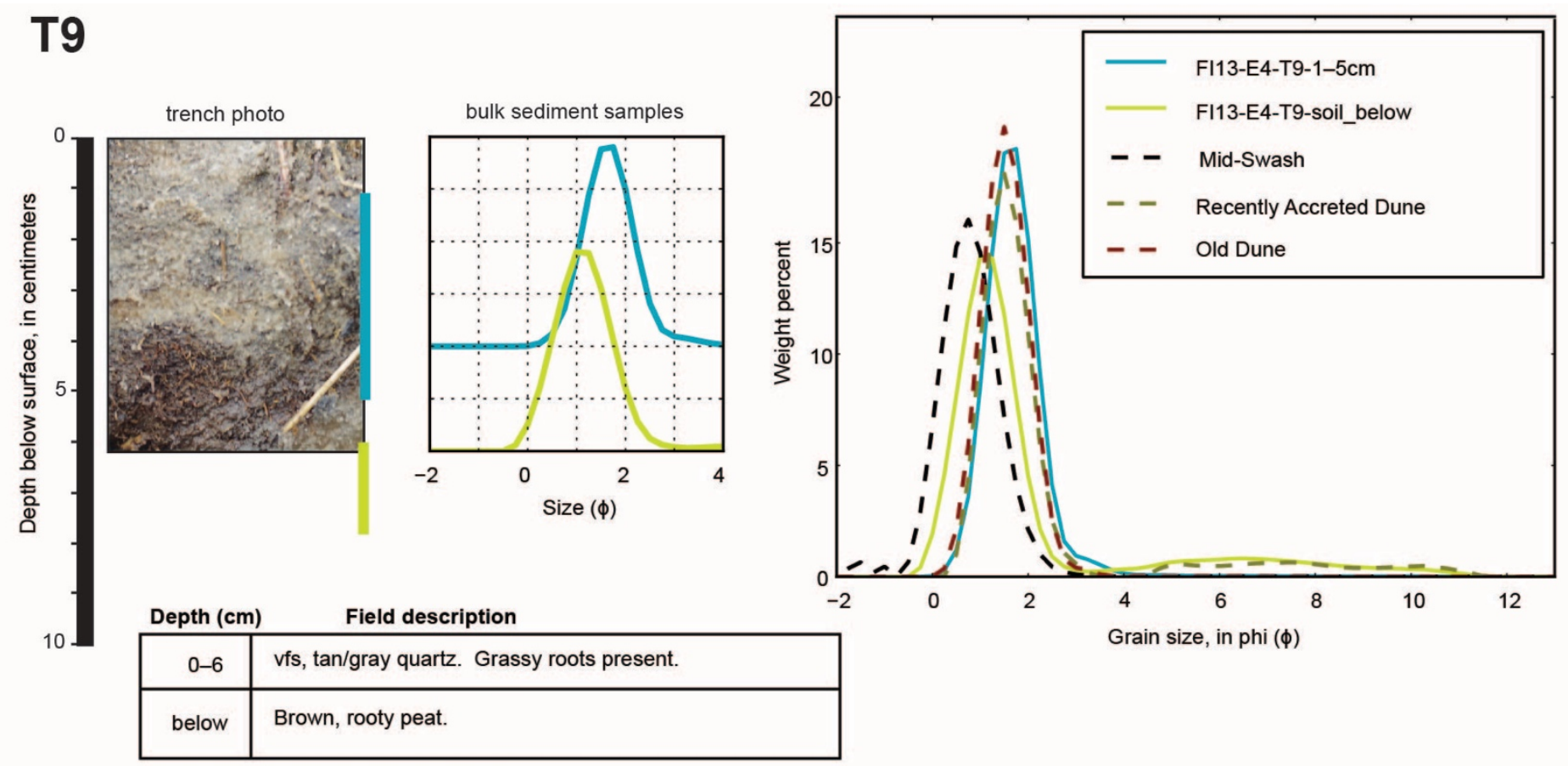

Figure 19. Diagram showing trench photograph, grain-size distributions for bulk sediment samples, graph comparing grain-size distributions, and table with stratigraphic description for trench T9 on Fire Island, New York. Layers in the photomosaiced trench photograph are delineated by black lines. Depths and a description for each layer are included in the table. The depths sampled are marked by the colored bar on the photomosaic. The graph shows the grain-size distributions stacked on top of one another (solid lines) compared to samples of possible sources (dashed lines). See figure 12 for explanation of abbreviations.

The results of the microtextural analysis revealed an assemblage with little variance between samples (fig. 21 and table 5). This is expected because the combination of a relatively short transport time during the hurricane acting on an already homogenous sediment source may limit the imprinting of identifiable microtextural signatures. However, a few basic trends may be observable from this analysis. A majority of the overwash deposits appear to have greater amounts of fresh surfaces and percussion marks, as is expected from aqueous transport (Costa and others, 2012). The dune sample, the reworked surface of T3 (FI13-E4-T3-0-3), and the gray-stained sand from T2 and T8 (FI13-E4-T2-13-16 and FI13-E4-T8-8-11) stand out from the rest of the samples and exhibit higher amounts of dissolution and (or) adhered particles. 

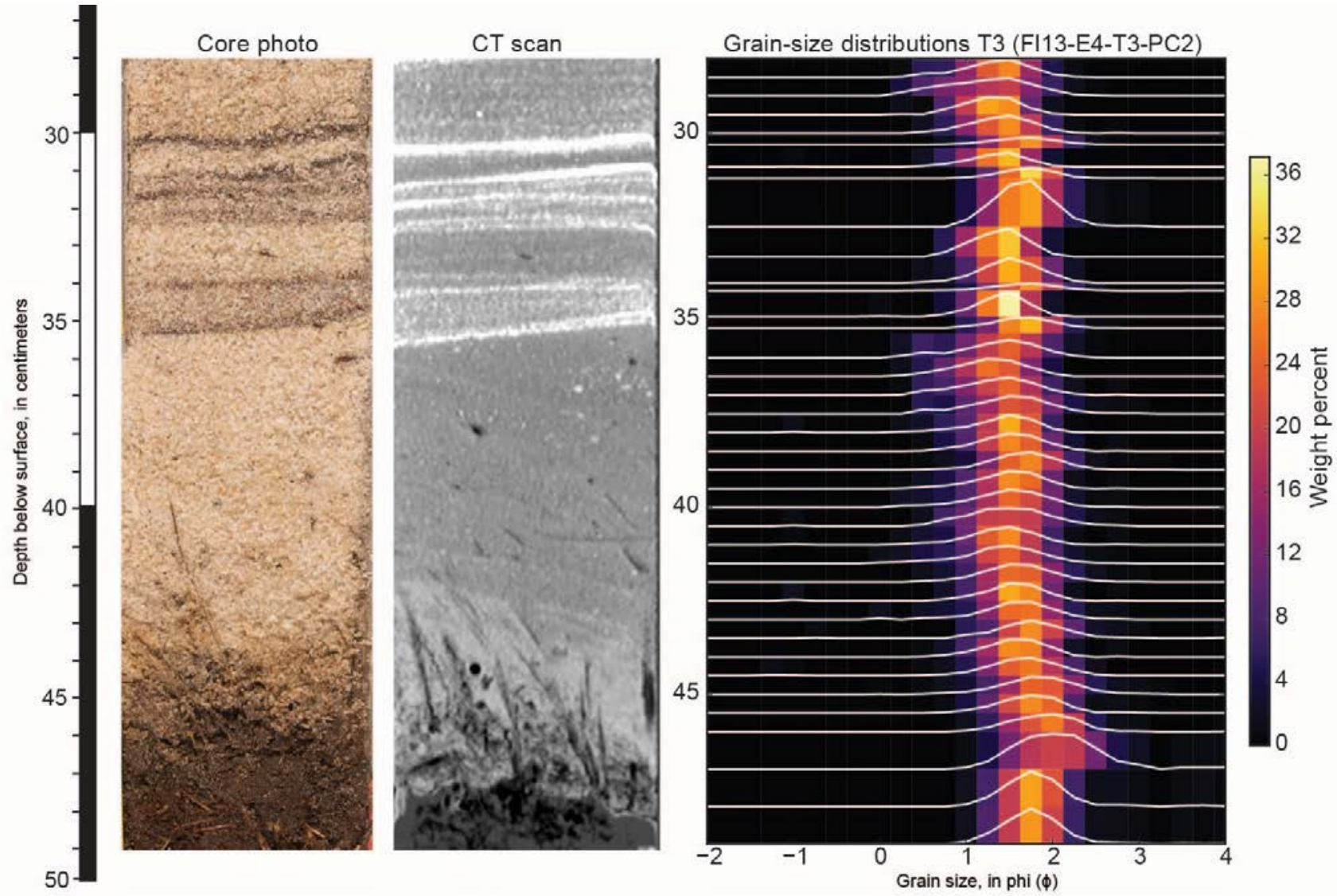

Figure 20. Diagram showing core photograph, x-ray computed tomography (CT) scan, and detailed, stacked grain-size distributions for core FI13-E4-T3-PC2. cm, centimeter; $\varphi$, phi.
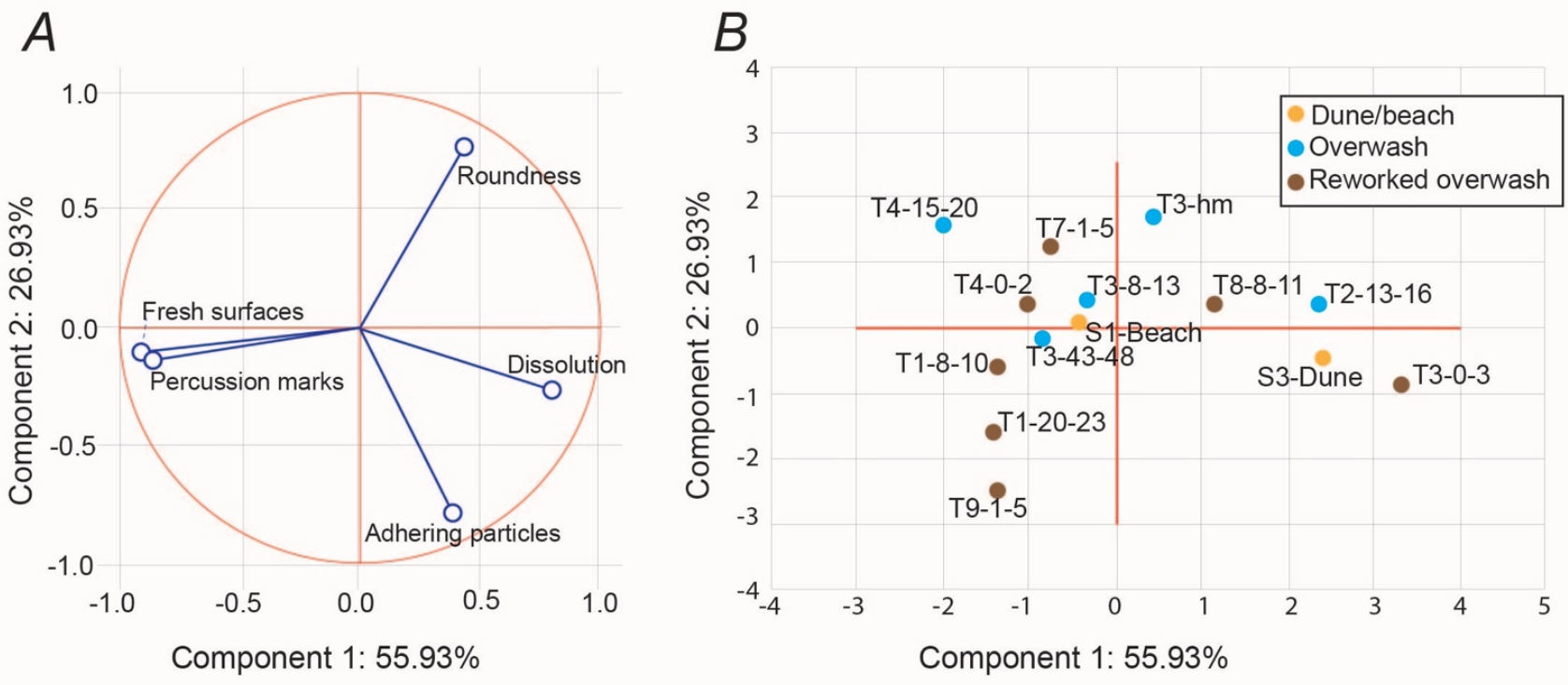

Figure 21. Graphs showing principal component analysis of microtextural features in sediment samples from Fire Island, New York. A, Projection of the variables (microtextural features) on the principal components. B, Projection of the samples on the principal components. Blue circles-sediments that were most likely primarily transported during the hurricane (by overwash). Brown circles-sediments on the overwash fan that appear to have been reworked by post-Hurricane Sandy eolian processes. Orange circles-surface samples from the beach and dune. $\%$, percent. 
Table 5. Microtextural analysis from scanning electron microscope (SEM) data from sediment samples collected on Fire Island, New York.

\begin{tabular}{|c|c|c|c|c|c|c|c|}
\hline Sample name & $\begin{array}{c}\text { SEM } \\
\text { sample } \\
\text { no. } \\
\end{array}$ & Sample description & Dissolution $^{1}$ & $\begin{array}{l}\text { Adhering } \\
\text { particles }^{1}\end{array}$ & $\begin{array}{l}\text { Fresh } \\
\text { surfaces }^{1}\end{array}$ & $\begin{array}{l}\text { Percussion } \\
\text { marks }^{1}\end{array}$ & Roundness $^{2}$ \\
\hline $\begin{array}{l}\text { FI13-E4-T3-hvy- } \\
\text { mineral-lamina }\end{array}$ & $2 \mathrm{~A}$ & $\begin{array}{l}\text { Heavy mineral } \\
\text { lamina }\end{array}$ & 1 & 0 & 2 & 1 & 4.0 \\
\hline FI13-E4-T4-0-2 & $2 \mathrm{~B}$ & Loose eolian & 1 & 1 & 3 & 2 & 4.0 \\
\hline FI13-E4-T7-1-5 & $3 \mathrm{~A}$ & Massive, $f-m$ sand & 1.5 & 0 & 2.5 & 2 & 4.0 \\
\hline FI13-E4-T4-15-20 & $3 \mathrm{~B}$ & Top laminated sand & 0 & 0 & 3 & 2 & 4.0 \\
\hline FI13-E4-T2-13-16 & $4 \mathrm{~A}$ & Gray sand & 2.5 & 0 & 1 & 1 & 4.0 \\
\hline FI13-E4-S3-Dune & $4 \mathrm{~B}$ & Dune & 2 & 1 & 1 & 1 & 4.0 \\
\hline FI13-E4-T3-0-3 & $5 \mathrm{~A}$ & Eolian & 3.5 & 2 & 1 & 1 & 4.0 \\
\hline FI13-E4-S1-Beach & $5 \mathrm{~B}$ & Beach & 2 & 2 & 3 & 2 & 4.0 \\
\hline FI13-E4-T3-43-48 & $6 \mathrm{~A}$ & $\begin{array}{l}\text { Rooted, faint } \\
\text { laminae }\end{array}$ & 1 & 1 & 3 & 2 & 4.0 \\
\hline FI13-E4-T9-1-5 & $6 \mathrm{~B}$ & $\begin{array}{l}\text { Rooted, very fine } \\
\text { sand }\end{array}$ & 1 & 1.5 & 3 & 2 & 3.0 \\
\hline FI13-E4-T1-20-23 & $7 \mathrm{~A}$ & Rooted, gray sand & 1.5 & 2 & 3 & 2 & 3.0 \\
\hline FI13-E4-T1-8-10 & $7 \mathrm{~B}$ & Med-coarse sand & 1 & 1 & 3 & 2 & 3.5 \\
\hline FI13-E4-T8-8-11 & $\begin{array}{c}\text { FI13- } \\
\text { E4- } \\
\text { T8 }\end{array}$ & $\begin{array}{l}\text { Very fine sand, } \\
\text { slightly gray }\end{array}$ & 2 & 1 & 1.5 & 1.5 & 4.0 \\
\hline FI13-E4-T3-8-13 & $\begin{array}{c}\text { FI13- } \\
\text { E4- } \\
\text { T3 }\end{array}$ & $\begin{array}{l}\text { Top of laminated } \\
\text { layer }\end{array}$ & 1 & 1 & 2 & 2 & 4.0 \\
\hline
\end{tabular}

${ }^{1}$ The proportion of grain surface occupied by each feature is estimated on a scale of 0 to 5 ( 0 to $>75$ percent of the grain surface).

${ }^{2}$ Roundness is classified using the Powers scale (Powers, 1953).

\section{Summary}

In 2013, the observed thickness of the washover deposit on Fire Island, New York, from Hurricane Sandy in 2012 varied from 1 to $100 \mathrm{~cm}$. However, the deposit thickness derived from preand post-Sandy lidar showed that about 10 percent of the thickness on the washover terrace and as much as 40 percent on the washover fan has been lost as a result post-Sandy reworking. Aerial photos from 5 days after Hurricane Sandy and about a year later show that the washover deposits tended to spread out in both the inland and along-shore directions, explaining the presence of the thin sandy deposit a year later at locations that were beyond the original extent of the washover fan. The trenches we have described were located beyond the influence of swash from post-Sandy storms, and significant eolian transport was observed while in the field, so we attribute most of the reworking of the deposit on the washover terrace and fan to eolian processes. Analysis of sediment samples taken from trench walls shows that the Hurricane Sandy deposit consists of well-sorted medium sand and is either massive or weakly inverse graded. Subsampling at a much finer interval ( $1 \mathrm{~cm}$ or less) from one core revealed a more complex pattern of fine-scale grading throughout the deposit. The massive sand layer that overlies the pre-Sandy surface shows an inland fining trend and a grain-size distribution very similar to the primary dune that was eroded during Hurricane Sandy. Results from microtextural analysis show that sand grains in the overwash deposit tend to exhibit fresh surfaces and percussion marks, as opposed to 
dissolution features and adhered particles observed on grains that were not eroded from the dune. Further grain-size and microtextural analyses will improve the ability to identify different transport processes that occur during hurricane overwash, which is essential for reconstructing hydrodynamic conditions from deposit characteristics.

\section{References Cited}

Costa, Pedro J.M., Andrade, C., Dawson, A.G., Mahaney, W.C., Freitas, M.C., Paris, R., and Taborda, R., 2012, Microtextural characteristics of quartz grains transported and deposited by tsunamis and storms: Sedimentary Geology, v. 275-276, p. 55-69, http://dx.doi.org/10.1016/j.sedgeo.2012.07.013.

Donnelly, C., Kraus, N.C., and Larson, M., 2006, State of knowledge on measurement and modeling of coastal overwash: Journal of Coastal Research, v. 22, no. 4, p. 965-991, http://dx.doi.org/10.2112/040431.1.

Goff, J., McFadgen, B.G., and Chagué-Goff, C., 2004, Sedimentary differences between the 2002 Easter storm and the 15th-century Okoropunga tsunami, southeastern North Island, New Zealand: Marine Geology, v 204, p. 235-250, http://dx.doi.org/10.1016/S0025-3227(03)00352-9.

Hapke, C.J., Lentz, E.E., Gayes, P.T., Clayton, A.M., Hehre, R., Schwab, W.C., and Williams, S.J., 2010, A review of sediment budget imbalances along Fire Island, New York - Can nearshore geologic framework and patterns of shoreline change explain the deficit?: Journal of Coastal Research, v. 26, no. 4, p. 510-522, http://dx.doi.org/10.2112/08-1140.1.

Hapke, C.J., Brenner, O.T., Hehre, R., and Reynolds, B.J., 2013, Coastal change from Hurricane Sandy and the 2012-13 winter storm season-Fire Island, New York: U.S. Geological Survey Open-File Report 2013-1231, 37 p., https://pubs.usgs.gov/of/2013/1231/.

Jaffe, B.E., and Gelfenbuam, G., 2007, A simple model for calculating tsunami flow speed from tsunami deposits: Sedimentary Geology, v. 200, no. 3-4, p. 347-361, http://dx.doi.org/10.1016/j.sedgeo.2007.01.013.

Lentz, E.E., and Hapke, C.J., 2011, Geologic framework influences on the geomorphology of an anthropogenically modified barrier island-Assessment of dune/beach changes at Fire Island, New York: Geomorphology, v. 126, no. 1-2, p. 82-96, http://dx.doi.org/10.1016/j.geomorph.2010.10.032.

McCallum, B.E., Wicklein, S.M., Reiser, R.G., Busciolano, Ronald, Morrison, Jonathan, Verdi, R.J., Painter, J.A., Frantz, E.R., and Gotvald, A.J., 2013, Monitoring storm tide and flooding from Hurricane Sandy along the Atlantic coast of the United States, October 2012: U.S. Geological Survey Open-File Report 2013-1043, 42 p., https://pubs.usgs.gov/of/2013/1043/.

Morton, R.A., and Sallenger, A.H., Jr., 2003, Morphological impacts of extreme storms on sandy beaches and barriers: Journal of Coastal Research, v. 19, p. 560-573.

Morton, R.A., Gelfenbaum, G., and Jaffe, B.E., 2007, Physical criteria for distinguishing sandy tsunami and storm deposits using modern examples. Sedimentary Geology, v. 200, no. 3-4, p. 184-207, http://dx.doi.org/10.1016/j.sedgeo.2007.01.003.

National Oceanic and Atmospheric Administration, National Ocean Service, National Geodetic Survey, 2013, Hurricane SANDY - Rapid Response Imagery of the Surrounding Regions: National Oceanic and Atmospheric Administration, National Ocean Service, National Geodetic Survey, Web site, accessed May 6, 2014, at http://ngs.woc.noaa.gov/storms/sandy/.

National Oceanic and Atmospheric Administration, National Ocean Service, Office for Coastal Management, 2012, 2011-2012 New York State Department of Environmental Conservation (NYSDEC) lidar - Coastal New York (Long Island and along the Hudson River): National Oceanic and Atmospheric Administration, National Ocean Service, Office for Coastal Management, Web site, accessed September 8, 2016, at https://coast.noaa.gov/dataviewer/\#/lidar/search/where:ID=1408/details/1408. 
Powers, M.C., 1953, A new roundness scale for sedimentary particles: Journal of Sedimentary Research, v. 23, p. 117-119, http://dx.doi.org/10.1306/D4269567-2B26-11D7-8648000102C1865D.

Shaw, J., You, Y., Mohrig, D., and Kocurek, G., 2015, Tracking hurricane-generated storm surge with washover fan stratigraphy: Geology, v. 43, no. 2, p. 127-130, http://dx.doi.org/10.1130/G36460.1.

Stockdon, H.F., Doran, K.J., Sopkin, K.L., Smith, K.E.L., and Fredericks, Xan, 2013, Coastal topography-Northeast Atlantic coast, post-hurricane Sandy, 2012: U.S. Geological Survey Data Series 765, https://pubs.usgs.gov/ds/765.

Switzer, A.D., and Jones, B.G., 2008, Large-scale washover sedimentation in a freshwater lagoon from the southeast Australian coast - Sea-level change, tsunami or exceptionally large storm?: The Holocene, v. 18, p. 787-803, http://dx.doi.org/10.1177/0959683608089214.

Tuttle, M.P., Ruffman, A., Anderson, T., and Jeter, H., 2004, Distinguishing tsunami from storm deposits in eastern North America-The 1929 Grand Banks tsunami versus the 1991 Halloween storm: Seismological Research Letters, v. 75, no. 1, p. 117-131, http://dx.doi.org/ 10.1785/gssrl.75.1.117.

U.S. Department of Agriculture, National Resources Conservation Service, 2014, Geospatial Data Gateway Web site, accessed May 6, 2014, at https://gdg.sc.egov.usda.gov.

Woodruff, J.D., Donnelly, J.P., Mohrig, D., and Geyer, W.R., 2008, Reconstructing relative flooding intensities responsible for hurricane-induced deposits from Laguna Playa Grande, Vieques, Puerto Rico: Geology, v. 36, no. 5, p. 391-394, http://dx.doi.org/10.1130/G24731A.1. 
ISSN 2331-1258 (online)

https://doi.org/10.3133/ofr20171014 